Research paper

\title{
Cytotoxic effects of dillapiole on MDA-MB-231 cells involve the induction of apoptosis through the mitochondrial pathway by inducing an oxidative stress while altering the cytoskeleton network
}

\author{
Adilson Kleber Ferreira a,1, Paulo Luiz de-Sá-Júnior ${ }^{\mathrm{a}, * *, 1}$, \\ Kerly Fernanda Mesquita Pasqualoto ${ }^{\mathrm{b}, 1}$, Ricardo Alexandre de Azevedo ${ }^{\mathrm{b}}$, \\ Diana Aparecida Dias Câmara ${ }^{a}$, André Santos Costa ${ }^{a}$, Carlos Rogério Figueiredo ${ }^{c}$, \\ Alisson Leonardo Matsuo ${ }^{c}$, Mariana Hiromi Massaoka ${ }^{c}$, Aline Vivian Vatti Auada ${ }^{b}$, \\ Ivo Lebrun ${ }^{\mathrm{b}}$, Mariana Celestina Frojuello Costa Bernstorff Damião ${ }^{\mathrm{d}}$, \\ Maurício Temotheo Tavares ${ }^{\mathrm{d}}$, Fátima Maria Motter Magri ${ }^{\mathrm{e}}$, Irina Kerkis ${ }^{\mathrm{a}}$, \\ Roberto Parise Filho ${ }^{\mathrm{d}, *}$ \\ a Laboratory of Genetics, Butantan Institute, Vital Brasil Avenue 1500, 05503-900 Sao Paulo, Brazil \\ biochemistry and Biophysical Laboratory, Butantan Institute, Vital Brasil Avenue 1500, 05503-900 Sao Paulo, Brazil \\ ${ }^{c}$ Experimental Oncology Unit (UNONEX), Microbiology, Immunology and Parasitology Dept, Federal University of São Paulo, Rua Botucatu 862, \\ 04023-062 Sao Paulo, Brazil \\ ${ }^{\mathrm{d}}$ Department of Pharmacy, School of Pharmaceutical Sciences, University of Sao Paulo, Prof. Lineu Prestes Avenue, 580, 05508-000 Sao Paulo, Brazil \\ ${ }^{\mathrm{e}}$ Center for Biological Sciences and Health (CCBS), Mackenzie Presbyterian University, Consolação Avenue, 930, 01302-907 Sao Paulo, Brazil
}

\section{A R T I C L E I N F O}

\section{Article history:}

Received 15 June 2013

Accepted 6 December 2013

Available online 16 December 2013

\section{Keywords:}

Piper aduncum

Dillapiole

Antitumoral

Apoptosis

Cell cycle

ROS

Molecular modeling

\begin{abstract}
A B S T R A C T
Breast cancer is the world's leading cause of death among women. This situation imposes an urgent development of more selective and less toxic agents. The use of natural molecular fingerprints as sources for new bioactive chemical entities has proven to be a quite promising and efficient method. Here, we have demonstrated for the first time that dillapiole has broad cytotoxic effects against a variety tumor cells. For instance, we found that it can act as a pro-oxidant compound through the induction of reactive oxygen species (ROS) release in MDA-MB-231 cells. We also demonstrated that dillapiole exhibits antiproliferative properties, arresting cells at the G0/G1 phase and its antimigration effects can be associated with the disruption of actin filaments, which in turn can prevent tumor cell proliferation. Molecular modeling studies corroborated the biological findings and suggested that dillapiole may present a good pharmacokinetic profile, mainly because its hydrophobic character, which can facilitate its diffusion through tumor cell membranes. All these findings support the fact that dillapiole is a promising anticancer agent.
\end{abstract}

(C) 2013 Elsevier Masson SAS. All rights reserved.

\section{Introduction}

Breast cancer is one of the most common human malignancies and the second leading cause of cancer-related deaths among women [1]. Despite substantial improvements in survival, resistance to therapy and subsequent progression of disease are still observed in metastatic patients [2]. Therapeutic regimens against

\footnotetext{
* Corresponding author. Tel.: +55 113091 3793; fax: +55 1130913815.

** Corresponding author. Tel.: +55 112627 9718; fax: +55 1130913815 .

E-mail addresses: paulsaj2001@yahoo.com.br (P.L. de-Sá-Júnior), roberto. parise@usp.br (R. Parise Filho).

${ }^{1}$ These authors contributed equally to this work.
}

breast cancer include both chemo- and radiotherapy, and in advanced stages of the disease surgery intervention can be required [3]. In spite of the many advances achieved in breast cancer treatment during the last ten years, many patients still succumb to this illness and new therapeutic approaches are needed [4]. Therefore, investigation of the molecular mechanisms involved in the development and progression of breast cancer is crucial for the discovery of effective and non-cytotoxic compounds for chemoprevention and treatment [5].

Natural products, mostly plant-derived products, occupy an important place in cancer chemotherapy [6]. Substances derived from medicinal plants are known to be effective chemo-preventive and/or antitumoral agents in experimental models of carcinogenesis [7]. The 
bioactive compounds from the Piperaceae family, for instance, which comprises a large variety of species [8,9], can be used as models for promising molecular modifications envisaging more specific therapeutic responses. Covering approximately three thousand species, the Piper genus is prominent for having distinct biological activities. Dillapiole (1) (Fig. 1), a phenylpropanoid, is the main component of Piper aduncum [10,11] essential oil and is also present in other Piper species such as: Piper banksii [12], Piper guineense [13,14], Piper novae hollandiae [15] and Piper marginatum [16]. Previous studies revealed its antileishmanial [17], anti-inflammatory [18], antifungal [10] and acaricidal [19] activity, nevertheless its cytotoxic effect have not been studied yet.

Safrole (2), a phenylpropanoid structural-related to dillapiole, is also found in Piper genus [20], which presents some interesting biological properties [21-24]. Previous research indicates that safrole (2) can induce apoptosis in human oral cancer cells [25] as well as cell cycle arrest and apoptosis in human leukemia cells through the endoplasmic reticulum (ER) stress-associated signaling based on the production of ROS [26]. The structural similarity of safrole and dillapiole is obvious, but there is no previous reports addressing a potential antitumor activity of dillapiole.

The current study was designed to evaluate the in vitro antitumor activity of dillapiole in MDA-MB-231 breast cancer cells. Our results have revealed that this molecule is cytotoxic to a variety of tumors cells. Also, dillapiole inhibited proliferation and migration of MDA-MB-231 cells by arresting them at the G0/G1 phase and the disruption of the cytoskeleton contributed to the inhibition of cell migration. Furthermore, the dillapiole apoptotic effects coincided with the increase in ROS production by the mitochondria, which is in agreement with the data showing that dillapiole induces mitochondrial depolarization, increasing the transient intracellular $\mathrm{Ca}^{2+}$, cytochrome $c$ release, caspase-3 activity in MDA-MB-231 cells. Additionally, the calculated molecular properties support the suitable pharmacokinetic and pharmacodynamic profiles of dillapiole. Overall, dillapiole is a compound with potential antitumor effects on MDA-MB-231 cells, suggesting that this molecule is a potential hit for the design of novel anticancer drugs.

\section{Materials and methods}

\subsection{General procedures}

Reagents and solvents were commercial grade, used as supplied. Chromatography separations were performed using 70-230 mesh silica gel. Thin-layer chromatography was carried out on Merck silica plates ( $0.25 \mathrm{~mm}$ layer thickness). NMR spectra were recorded using a Bruker AC-300 Spectrometer at $300 \mathrm{MHz}\left({ }^{1} \mathrm{H}\right)$ and $75 \mathrm{MHz}$ $\left({ }^{13} \mathrm{C}\right)$ with tetramethylsilane as an internal reference and $\mathrm{CDCl}_{3}$ as a solvent. Chemical shifts are given in parts per million (ppm), coupling constants in Hertz $(\mathrm{Hz})$, and splitting patterns were designated as follows: s, singlet; br s, broad singlet; $d$, doublet; $t$, triplet; q, quartet, and $\mathrm{m}$, multiplet. Gas chromatography-mass spectrometry (GC-MS) was performed using a 17A/QP5050A Shimadzu-brand GC-MS apparatus: Class 5000 software; column: BXP5-30 m, $0.25 \mathrm{~mm}$ ID; helium as carrier gas (flow rate $2.5 \mathrm{~mL}$ /
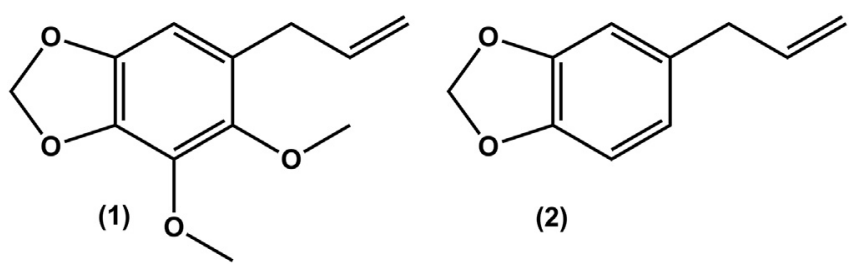

(2) min). The ionization mode was EL at $70 \mathrm{eV}$. Temperature program was from $60^{\circ} \mathrm{C}$ (rate $8{ }^{\circ} \mathrm{C} / \mathrm{min}$ ) to $320^{\circ} \mathrm{C}(35 \mathrm{~min})$. The detector and injector temperatures were both $250^{\circ} \mathrm{C}$.

\subsection{Extraction of dillapiole from P. aduncum}

P. aduncum leaves were collected in March and August, 2011, in Ubatuba, São Paulo, Brazil. Identification was carried out at the Botanical Laboratory of Mackenzie Presbyterian University (MPU). The $P$. aduncum leaves exsiccate was stored in the MPU herbarium (no. 01092). The collected vegetable material underwent extraction of its essential components through hydrodistillation, using a modified Clevenger-type apparatus. The crude essential oil was extracted with dichloromethane, then dried with anhydrous $\mathrm{Na}_{2} \mathrm{SO}_{4}$, filtered, and kept in a freezer $\left(-15^{\circ} \mathrm{C}\right)$, using an amber glass flask [18].

\subsection{Purification of dillapiole (1)}

Pure dillapiole was used to carried out the bioassays. Purification and isolation procedures were perform as previously reported in Refs. [17,18]. Briefly, the crude essential oil was obtained by hydrodistillation and diluted with dichloromethane. GS-MS chromatography was carried out to determine the percentage of dillapiole in crude extract. The results showed that dillapiole is the majority compound and represents for almost $89 \%$ of the essential oil. Mass spectrometry data analysis together with hydrogen nuclear magnetic resonance spectroscopy $\left({ }^{1} \mathrm{H}\right.$ NMR) confirmed that dillapiole was the main component of the crude extract. After that, dillapiole was isolated and purified by column chromatography using hexanes/ethyl acetate (1:1), as solvent system. Additionally, the isolated sample was characterized by GC-MS and was further used to evaluate the cytotoxic activity. Viscous yellow liquid. (1.5 g yield ${ }^{1} \mathrm{H} \mathrm{NMR}\left(\mathrm{CDCl}_{3}, 300 \mathrm{MHz}, \delta=\mathrm{ppm}\right): 3.31$ (d, 2H, H-8); 3.81 (s, $3 \mathrm{H}, \mathrm{H}-11$ ); 4.08 (s, 3H, H-12); 5.05-5.15 (m, 2H, H-10); 5.88-6.05 (m, 1H, H-9); 5.98 (s, 2H, H-1); 6.40 (s, 1H, H-6). ${ }^{13} \mathrm{C}$ NMR (CDCl3, $75 \mathrm{MHz}, \delta=\mathrm{ppm}$ ): 34.5 (C8); 60.3 (C11); 60.8 (C12); 101.5 (C1); 102.4 (C6); 115.9 (C10); 122.1(C5); 132.3 (C2); 136.5 (C9); 142.0 (C7); 143.6 (C4); 145.1 (C3).

\subsection{Molecular modeling approach}

The three-dimensional (3D) molecular model of dillapiole was built, in its neutral form, using the HyperChem 7.0 MM + force field (Hypercube, Inc., 2002), without any constrains, and employing the crystal data from 6-[1-(4-ethoxyphenyl)ethyl]-5-methoxy-1,3benzodioxole [27] as starting geometry. Partial atomic charges were computed with AM1 semiempirical method [28], also implemented in HyperChem 7.0 (Hypercube, Inc., 2002). MOLSIM 3.2 software [29] was used to carry out energy-minimization (steepest descent and conjugate gradient methods; convergence criterion of $0.01 \mathrm{kcal} / \mathrm{mol}$ ) and molecular dynamics (MD) simulations ( $1 \mathrm{~ns}$; step size of $1 \mathrm{fs}$ ). Output trajectory file was recorded every 20 ps resulting in a conformational ensemble profile (CEP) of 50,000 conformers. The lowest-energy conformation was selected from the CEP equilibrium region, and the total potential energy $\left(E_{\mathrm{T}}\right)$ of that conformation corresponds to the summation of the following intramolecular energy contributions: stretching $\left(E_{\text {stretch }}\right)$, bending $\left(E_{\text {bend }}\right)$, torsional $\left(E_{\text {tors }}\right)$, Lennard-Jones or 1-4 interactions $\left(E_{1-4}\right)$, electrostatic ( $\left.E_{\text {charge }}\right)$, van der Waals $\left(E_{\mathrm{vdW}}\right)$, hydrogen bonding $\left(E_{\mathrm{Hb}}\right)$, and solvation $\left(E_{\mathrm{solv}}\right)$. Then, the lowest-energy conformation was energy-minimized [29] and, subsequently, used as starting geometry to calculate molecular properties of distinct nature. Electronic properties as partial atomic charges from electrostatic potential using a grid based method [30] and the

Fig. 1. Chemical structures of dillapiole (1) and safrole (2). 
related electrostatic potential (EP) were computed with the B3LYP (Becke, three-parameter, Lee-Yang-Parr) [31] hybrid functional and 6-31(d,p) basis set [32]. EP maps were calculated onto a Connolly molecular surface, using a color scheme ranging from -0.046 (intense red) to 0.046 (intense blue). Negative values of EP (higher electronic density distribution) are depicted in red and positive values in blue (lower electronic density distribution) [33]. Also, the calculated $n$-octanol/water partition coefficient $(C \log P)$, which is a measure of molecular hydrophobicity, was computed based upon the Viswanadhan and co-workers method [34], implemented in Marvin 5.8.0 package, Calculator Plugins [35].

\subsection{Cell lines and cell culture}

The human breast adenocarcinoma (MCF-7 and MDA-MB-231) and the melanoma (Sbcl-2; Mel-85; SK-MEL-28) cell lines were purchased from the American Type Culture Collection (Manassas, VA, USA). The cells were maintained in RPMI-1640 medium supplemented with $10 \%$ fetal calf serum (FCS) (Cultilab, Campinas, SP, Brazil), containing penicillin (100 units $/ \mathrm{mL})$ and streptomycin $(100 \mu \mathrm{g} / \mathrm{mL}$, Cultilab, Campinas, SP, Brazil). All cells were cultured at $37{ }^{\circ} \mathrm{C}$ in a fully humidified incubator with $5 \% \mathrm{CO}_{2}$. All experiments described were performed at least three times using cells in the exponential growth phase.

\subsection{Cell viability assay}

Tumor cells in the logarithmic growth phase were plated at a density of $10^{4}$ cells/100 $\mu \mathrm{L}$ into 96-well plates and allowed to adhere overnight. For the evaluation whether caspases are involved with the cytotoxic effects of dillapiole, cells were pre-treated with a specific inhibitor of cyclophilin and with $40 \mu \mathrm{M}$ Z-VAD-fmk, a pancaspase inhibitor, for $2 \mathrm{~h}$. Subsequently, the culture medium was replaced with medium containing different concentrations of dillapiole. After $24 \mathrm{~h}$ of treatment, cell viability was determined by MTT (3-[4,5 dimethylthiazol-2-yl]-2,5-diphenyltetrazolium bromide). Briefly, $20 \mu \mathrm{L}$ of MTT reagent (Sigma-Aldrich, St. Louis, USA) were added to each well at a final concentration of $5 \mathrm{mg} / \mathrm{mL}$, incubated for $4 \mathrm{~h}$ at $37^{\circ} \mathrm{C}$ and centrifuged at $2000 \mathrm{rpm}$ for $10 \mathrm{~min}$. The medium was discarded and $100 \mu \mathrm{L}$ of dimethylsulfoxide were added to each well. Each experiment was performed using six replicates for each drug concentration and was repeated in tree independent experiments.

\subsection{Wound-healing assay}

MDA-MB-231 $\left(2.5 \times 10^{5}\right.$ cells $)$ were grown to confluence in a $12-$ well plate, placed in medium containing $1 \%$ serum for $24 \mathrm{~h}$ at $37{ }^{\circ} \mathrm{C}$ in an atmosphere of $5 \% \mathrm{CO}_{2}$. Upon reaching confluence, the cell layer was scratched with a sterile plastic tip and then washed twice with culture medium. Next, serum was increased to $5 \%$ to facilitate cell migration and the cells were treated with $25 \mu \mathrm{M}$ or $50 \mu \mathrm{M}$ dillapiole for $48 \mathrm{~h}$. Cell migration was recorded using a Nikon TE2000E microscope system (Nikon Instrument). The area of wound healing was calculated using WimScratch software.

\subsection{Cell cycle analysis}

MDA-MB-231 cells were synchronized by deprivation of serum for $24 \mathrm{~h}$ and induced to reenter the cell cycle by the subsequent addition of serum. Cells were treated for $24 \mathrm{~h}$ with 25, 50 and $100 \mu \mathrm{M}$ dillapiole. Next, cells were collected and fixed with cold $70 \%$ ethanol and stored at $-20^{\circ} \mathrm{C}$. Cells were washed, re-suspended in PBS and incubated at $37{ }^{\circ} \mathrm{C}$ for $45 \mathrm{~min}$ with $10 \mathrm{mg} / \mathrm{mL}$ RNase and $1 \mathrm{mg} / \mathrm{mL}$ propidium iodide (PI) (SIGMA, St. Louis, MO). Flow cytometric analysis was performed using a FACScalibur flow cytometer (Becton Dickinson, San Jose, CA). Cell DNA content in the different cell cycle phases was determined using Modfit LT software (Verity Software House, Topsham, ME).

\subsection{Evaluation of apoptosis by flow cytometry}

For the detection and evaluation of apoptosis, MDA-MB-231 cells were treated with 25,50 and $100 \mu \mathrm{M}$ dillapiole for $24 \mathrm{~h}$, then washed with PBS (500 $\mu \mathrm{L} /$ well), harvested (including suspension cells) and incubated with $2 \mu \mathrm{M}$ YO-PRO-1 (Life Technologies Eugene, Oregon, USA) and $10 \mu \mathrm{M}$ of PI in PBS for $30 \mathrm{~min}$ at room temperature in the dark. The cells were immediately analyzed by flow cytometry using $488 \mathrm{~nm}$ excitation in a FACScalibur flow cytometer (Scalibur-Becton Dickinson, San Jose, CA). Data from three independent experiments were analyzed using the FlowJo software.

\subsection{Measurement of the mitochondrial transmembrane potential}

The mitochondrial membrane potential $(\Delta \Psi \mathrm{m})$ was evaluated using the tetramethyl-rhodamine ethyl ester (TMRE) probe (Invitrogen-Molecular Probes). Briefly, MDA-MB-231 cells $\left(10^{6}\right.$ cells/ well) were seeded in 6-well plates and incubated for $24 \mathrm{~h}$. After $24 \mathrm{~h}$ of treatment with 25 and $50 \mu \mathrm{M}$ dillapiole, $20 \mathrm{nM}$ TMRE were added to cell cultures maintained at $37^{\circ} \mathrm{C}$ for $45 \mathrm{~min}$. Fluorescence was measured using a FACScan flow cytometry system (Becton Dickinson, San Jose, CA). A total of 10,000 cells/sample were analyzed and the mean fluorescence intensity and percentage of cells in each population were recorded.

\subsection{Measurement of changes in free intracellular calcium concentration $\left(\left[\mathrm{Ca}^{2+}\right] \mathrm{i}\right)$ by microfluorimetry}

Changes in $\left[\mathrm{Ca}^{2+}\right]$ i were determined by microfluorimetry using FlexStation III (Molecular Devices Corp., Sunny Valley, CA). MDAMB-231 cells were seeded at a density of $5 \times 10^{4}$ cells per well in black-well plates with clear bottom in serum-free medium. Cells were then incubated for $60 \mathrm{~min}$ at $37{ }^{\circ} \mathrm{C}$ with the Flexstation Calcium Kit in the presence of $2.5 \mathrm{mM}$ probenecid in a final volume of $200 \mathrm{~mL} /$ well. Samples were excited at $485 \mathrm{~nm}$, and fluorescence emission was detected at $525 \mathrm{~nm}$. Samples were read at $1.52 \mathrm{~s}$ intervals for $120 \mathrm{~s}$ with a total of 79 read-outs per well. After Basal fluorescence intensity for $\left[\mathrm{Ca}^{2+}\right]$ i levels in non-stimulated cells were monitored for $20 \mathrm{~s}$, then $25 \mu \mathrm{M}$ dillapiole or $50 \mathrm{mM}$ ATP (positive control) or $50 \mathrm{mM} \mathrm{H}_{2} \mathrm{O}$ (negative control), were added to the cells. Next, the induction of transient $\left[\mathrm{Ca}^{2+}\right] \mathrm{i}$ was monitored for up to $100 \mathrm{~s}$. Responses to agonist addition were determined as peak fluorescence minus the basal fluorescence intensity using the SoftMax1Pro software (Molecular Devices Corp.).

\subsection{Caspase-3 activity assay}

After $12 \mathrm{~h}$ of treatment with 25 or $50 \mu \mathrm{M}$ dillapiole, the cells were washed twice with cold PBS and then scraped in $5 \mathrm{~mL}$ of cold protease assay buffer ( $25 \mathrm{mM}$ HEPES, pH 7.5, $5 \mathrm{mM}$ EDTA, $2 \mathrm{mM}$ dithiothreitol, and $0.1 \%$ detergent) and sonicated to lyse the cells. The lysates were collected and stored at $-70{ }^{\circ} \mathrm{C}$ until analyzed. Briefly, $50 \mu \mathrm{L}$ of $1 \times$ reaction buffer were added to each well used in the assay and incubated at $37^{\circ} \mathrm{C}$ for $5 \mathrm{~min}$. Caspase activity was measured using the substrate Ac-YVAD-AMC using the caspase-3 fluorometric assay kit from Biovision. Flow cytometric analysis was performed using a FACScan flow cytometry system (Becton Dickinson, San Jose, CA). Data from three independent experiments were analyzed using the FlowJo software. 


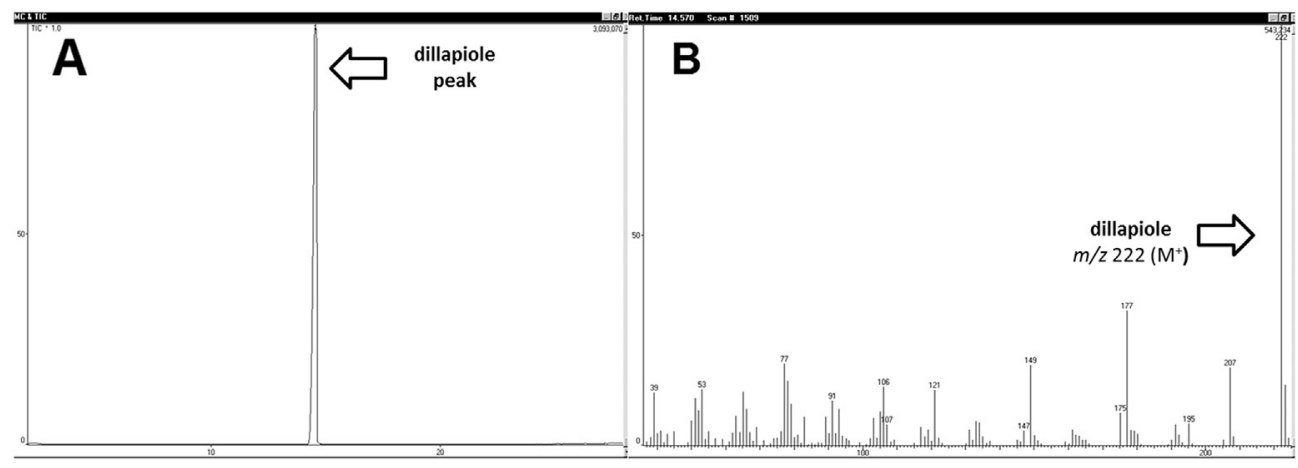

Fig. 2. GC-MS analysis of pure dillapiole. (A) Chromatogram and (B) mass spectrum obtained for the pure compound.

\subsection{Determination of cytochrome c by flow cytometry}

MDA-MB-231 cells were treated with 25 or $50 \mu \mathrm{M}$ dillapiole for $12 \mathrm{~h}$ and stained with PE-labeled anti-human antibody or isotype control IgG (Santa Cruz, CA, USA). Cells were first fixed with 3.7\% paraformaldehyde and permeabilized with Triton X-100 0.02\%, then stained with FITC labeled anti-cytochrome $c$ or isotype control antibody (Santa Cruz, CA, USA). The percentages of cells expressing Bcl-2, Cyclin D1 and p53 was determined using a FACScalibur flow cytometer (Becton Dickinson, San Jose, CA). Data from three independent experiments were analyzed using the FlowJo software.

\subsection{Confocal laser scanning microscopy}

MDA-MB-231 cells were seeded onto sterile glass cover slips in 24-well plates. Next, cells were treated with dillapiole at the concentration of $25 \mu \mathrm{M}$ or $50 \mu \mathrm{M}$. After treatment, the cells were fixed with $3.7 \%$ paraformaldehyde and permeabilized in $0.02 \%$ triton- $x$ diluted in PBS containing $10 \%$ bovine fetal serum. To analyze the effect of dillapiole on actin filaments, cells were labeled with FITCphalloidin (Invitrogen-Molecular Probes, Eugene, OR) in a buffer containing $0.5 \%$ Triton X-100, $1 \mathrm{mg} / \mathrm{mL}$ RNase in $2 \times$ PBS. For mitochondria studies, the cells were stained with MitoTracker ${ }^{\circledR}$ red
A

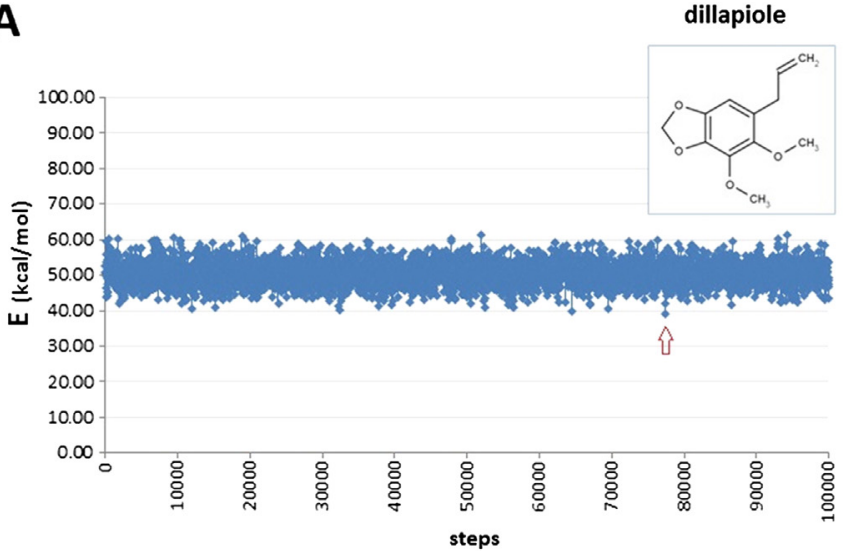

A-1

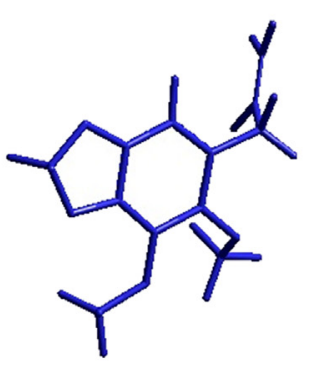

A-2

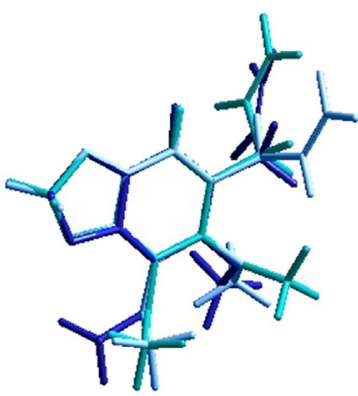

B

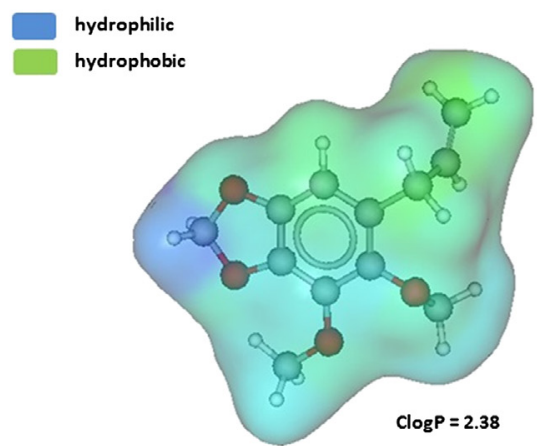

C

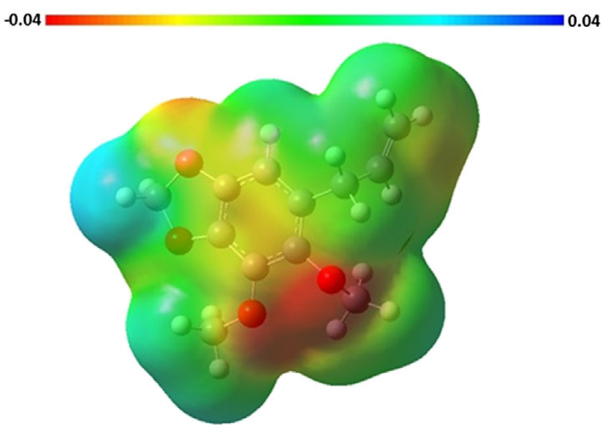

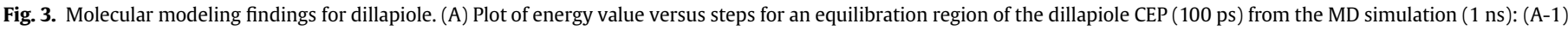

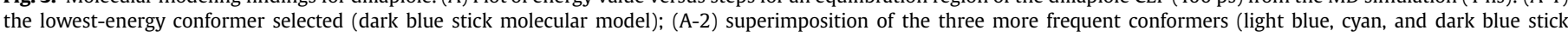

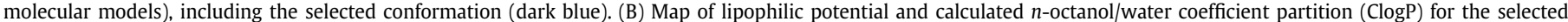

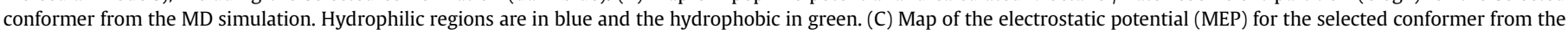

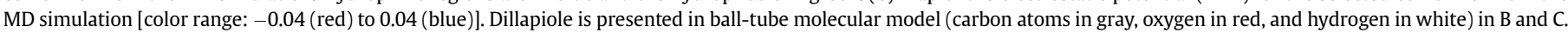



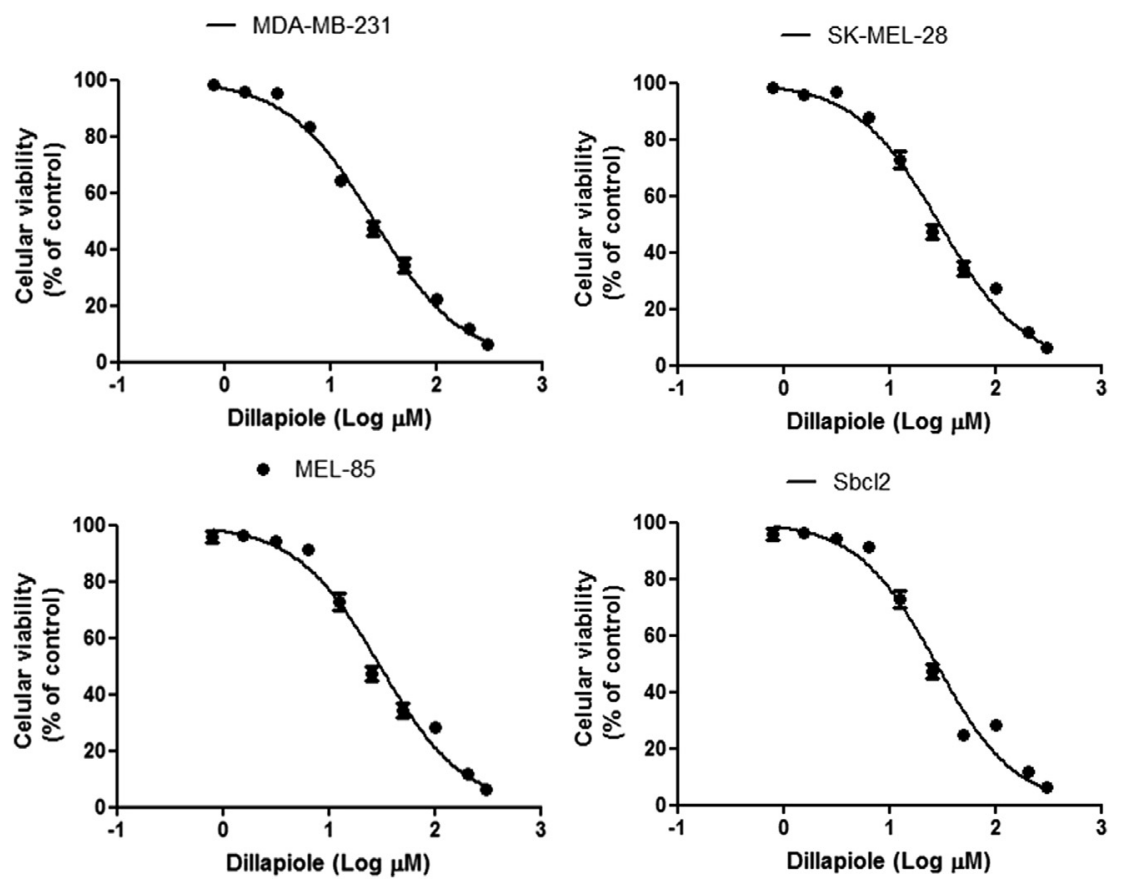

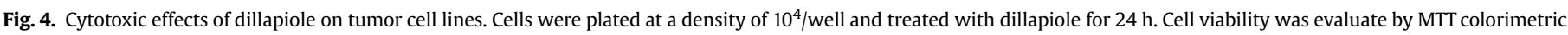

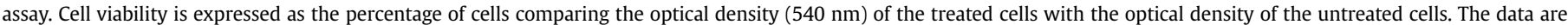
representative of three independent experiments performed in triplicate.

for 45 min under growth conditions. For ROS detection, cells were incubated with $2^{\prime}, 7^{\prime}$-dichlorofluorescein diacetate (H2DCFH-DA, Sigma, St Louis MO) (5 mM), for $10 \mathrm{~min}$ at $37^{\circ} \mathrm{C}$ in the dark. Image analysis was performed with a confocal laser scanning microscope (Carl Zeiss LSM 700; Leica, Mannheim, Germany). Post-acquisition image processing, background correction, adjustment of brightness and contrast and export to tiff format were done with Image J software (version 14.1) National Institutes of Health (Bethesda, Maryland, USA).

\subsection{Statistical analysis}

All values were expressed as mean \pm SD. Each value is the mean of at least three independent experiments in each group. For significance analyses Student's $t$-tests and One way analysis of variance (ANOVA) were calculated using GraphPad Prism 4.0. $p$ values $<0.05,0.01$ and 0.001 were considered significant.

\section{Results}

\subsection{GC-MS analysis of dillapiole}

After purification, GC-MS analysis revealed the presence of only one compound (Fig. 2). The gas chromatogram, presented in Fig. 2A, shows that dillapiole was successfully isolated and purified from its essential oil (purity 100\%). Furthermore, according to the mass spectra analysis (Fig. 2B), the content had a molecular mass corresponding to that found for dillapiole $\left(\mathrm{m} / z 222\left[\mathrm{M}^{+}\right]\right)$.

\subsection{Molecular modeling findings}

The purpose of a theoretical approach was to find a more energetically favorable conformation for dillapiole, to calculate its molecular properties and, finally, to provide some insights regarding structure-activity relationships. The findings from MD simulations are presented in Fig. 3A. MD simulations of dillapiole reached the thermodynamic equilibrium in approximately 300,000 simulation steps. Part of the CEP (100 ps) from where the lowest-energy conformation (dark blue; A-1) was chosen as well as the superimposition of the more frequent 3D conformers (A-2) can be visualized (stick or tube molecular models). The side chain of dillapiole, which has a double bond between the $C_{11}$ and $C_{12}$ positions, did not remain in the same plane of the benzodioxole ring. The more frequent conformers present the side chain turned to the back side of the benzodioxole ring, and the total potential energy $\left(E_{\mathrm{T}}\right)$ found for the selected conformer from CEP was $35.35 \mathrm{kcal} / \mathrm{mol}$.

Lipophilicity, expressed through the calculated $n$-octanol/water partition coefficient $(\mathrm{ClogP})$ and visualized through the maps of lipophilic potential (MLP), was also considered (Fig. 3B). Dillapiole presented a $C \log P$ value of 2.38 , indicating a hydrophobic character, meaning the ability to cross hydrophobic barriers such as cell membranes in order to reach their target, for instance. Even when no barriers are to be crossed (such as in in vitro studies), the drug

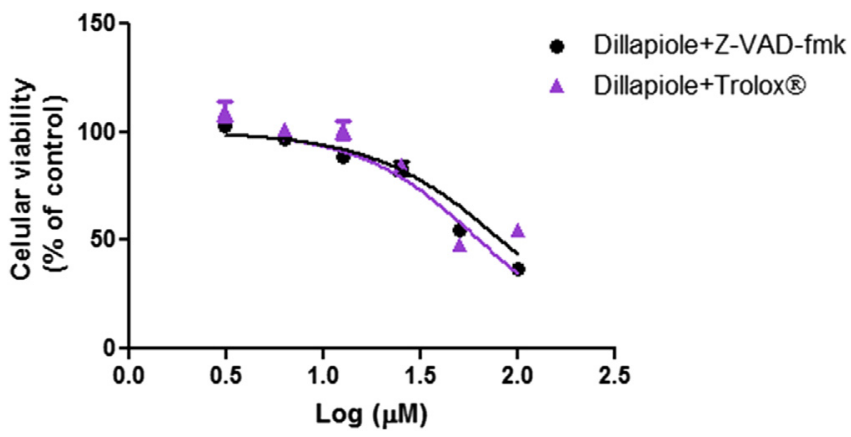

Fig. 5. Cytotoxic effects of Dillapiole on MDA-MB-231. Cells were plated at a density of $10^{4} /$ well and pre-treated with $40 \mu \mathrm{M} z$-VAD-fmk, a pan-caspase inhibitor and an antioxidant agent, Trolox ${ }^{\circledR}$, followed by the addition of dillapiole. The MTT shows that $\mathrm{z}$-VAD-fmk and Trolox ${ }^{\circledR}$ reduce the cytotoxic potency of dillapiole on MDA-MB-231 after $24 \mathrm{~h}$ of treatment. The data are representative of three independent experiments performed in triplicate. 
has to interact with a target system such as an enzyme or receptor where the binding site is usually hydrophobic. Otherwise, the drug should not be so hydrophobic that it would be poorly soluble in the aqueous phase such that it might get 'trapped' in fat depots and never reach the intended interaction site. In addition, a hydrophilic/ hydrophobic molecular balance is needed to provide suitable pharmacodynamics and pharmacokinetic profiles. The MLP property gives the information regarding that balance and can be explained using a color scheme, where blue corresponds to hydrophilic regions and green to hydrophobic regions.

Regarding the partial atomic electrostatic potential charges (ESP, CHELPG), the $\mathrm{C}_{10}$ atom (attached to aromatic ring) in dillapiole is positively charged $(0.3254)$. This datum indicates that dillapiole could likely suffer a nucleophilic attack, but only in the opposite face of its side chain direction where there is no steric hindrance. The electronic density distribution can be visualized through the EP map (Fig. 3C), and a more neutral/positive region can be visualized on the side chain, particularly on the $C_{10}$ atom (green). The electronic properties are also fundamental in the molecular recognition process, and are more strictly related to the pharmacodynamics profile (ligand-receptor interactions).

\subsection{Dillapiole induces cytotoxic effects on tumor cell lines}

The cytotoxic properties of dillapiole were investigated using the MTT assay, a well-documented method to assess cell viability. Tumor

\section{A}

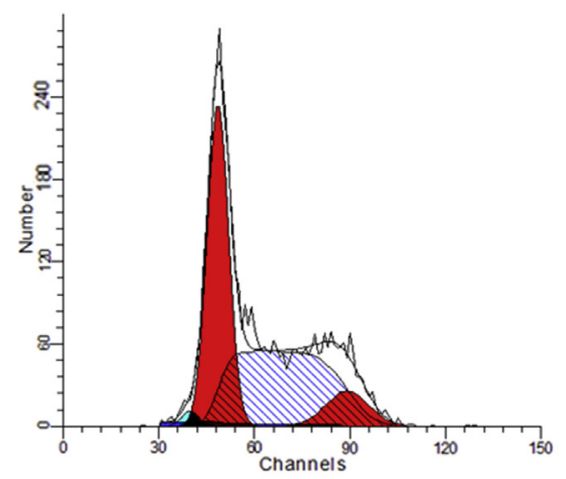

Dillapiole $25 \mu \mathrm{M}$

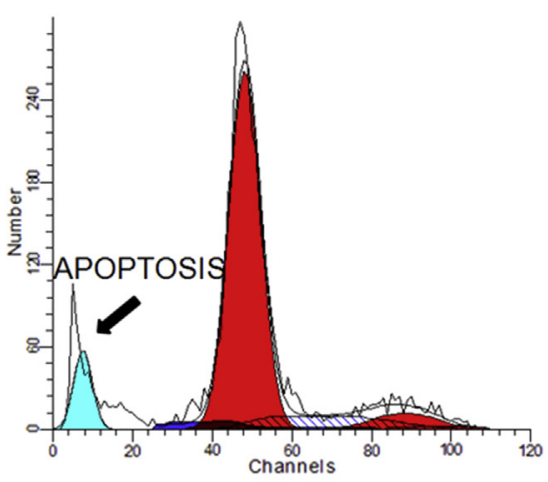

DNA Content
B
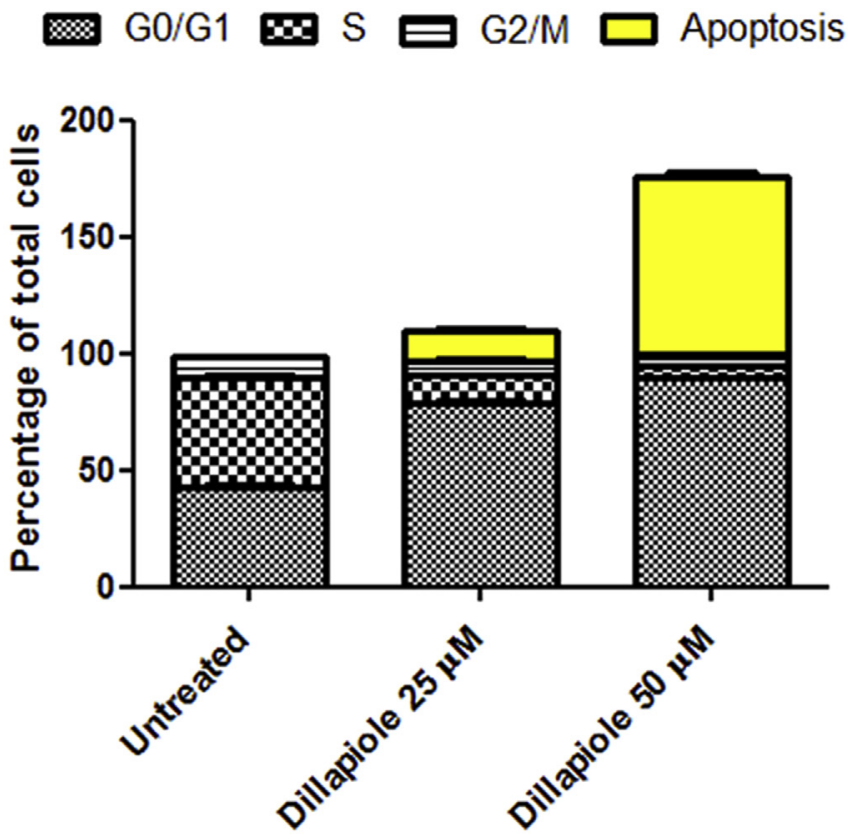

C

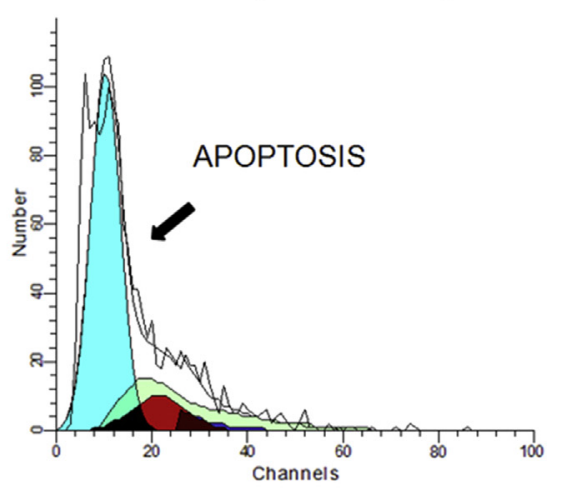

Dillapiole $50 \mu \mathrm{M}$

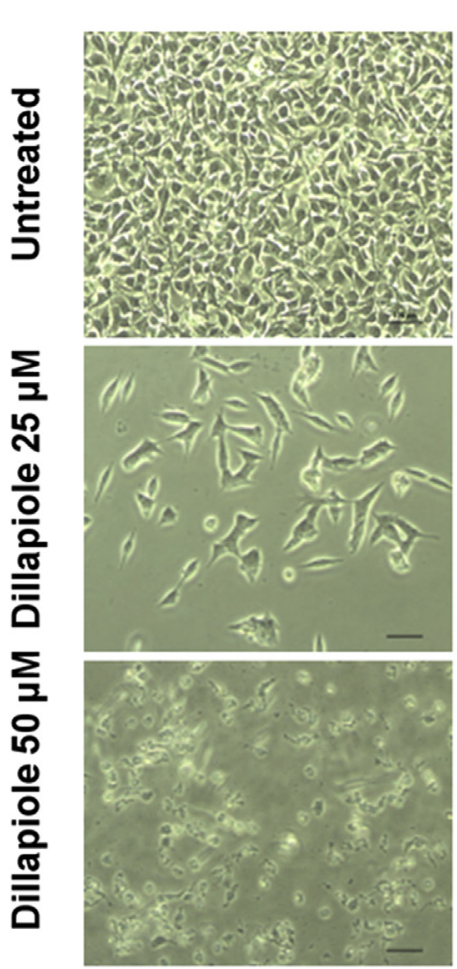

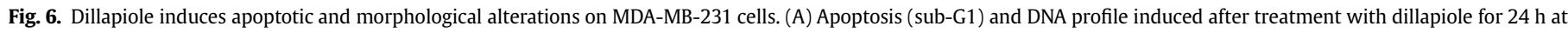

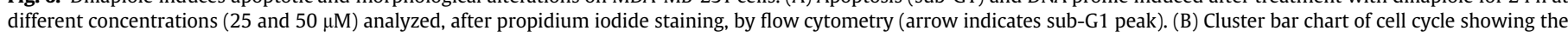

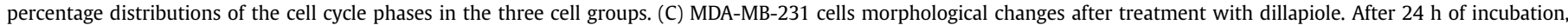

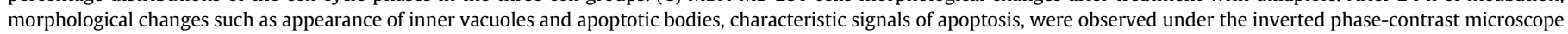
and were also photographed. The data are representative examples for duplicate tests. Original magnification, $\times 200$. 
cells were incubated for $24 \mathrm{~h}$ with different concentrations of the compound. The results show that dillapiole presents cytotoxic effects, reducing cell viability in all tumor cells tested in this work. The $\mathrm{IC}_{50}$ values of dillapiole on MDA-MB-231, SK-MEL-28, MEL-85 and Sbcl 2 were $25 \mu \mathrm{M}, 27 \mu \mathrm{M}, 28 \mu \mathrm{M}$ and $26 \mu \mathrm{M}$, respectively. These results indicate that there is no difference between tumor cell lines in response to dillapiole (Fig. 4). Next, we evaluated its anticancer effects using MDA-MB-231 cells as a model. Prior to treatment with dillapiole, cells were pre-incubated with a pan-caspase inhibitor, zVAD-fmk, and an antioxidant agent, Trolox ${ }^{\circledR}$. Interestingly, the inhibitors dramatically decreased cytotoxic effects of dillapiole on MDA-MB-231 cells. The $\mathrm{IC}_{50}$ value of dillapiole on cells pre-treated with z-VAD-fmk is $63 \mu \mathrm{M}$, and with Trolox ${ }^{\circledR}$ is $82 \mu \mathrm{M}$ (Fig. 5). An unanticipated finding is that dillapiole is cytotoxic in a caspasedependent manner. Additionally, the release of ROS indicates a possible mechanism of action of dillapiole on MDA-MB-231 cells.

\subsection{Cell cycle changes induced by apoptotic effects of dillapiole on MDA-MB-231 cells}

In this study, we investigated the anti-proliferative effects of dillapiole on MDA-MB-231 cells. Our data clearly show that the cytotoxic effects of dillapiole correlate with its ability to induce apoptosis as evidenced by the sub-G1 apoptotic peak. As shown in Fig. 6A, induction of apoptosis in MDA-MB-231 cells was more efficient $\left({ }^{* *} p<0.01\right)$ at $50 \mu \mathrm{M}$ than at $25 \mu \mathrm{M}$, reducing the number of tumor cells between the $\mathrm{S}$ and G2/M phases of the cell cycle. Additionally, treatment with $25 \mu \mathrm{M}$ dillapiole does not induce apoptosis, but exhibits a higher potency in blocking cell progression by arresting cells at the G0/G1 phase $\left({ }^{* *} p<0.01\right)$ (Fig. 6B). When treated with $50 \mu \mathrm{M}$ dillapiole, typical apoptosis morphological changes, such as the retraction of membrane and nuclei, were also observed (Fig. 6C). These findings further support the hypothesis that dillapiole, at $50 \mu \mathrm{M}$, induces apoptosis in MDA-MB-231 cells.

\subsection{Dillapiole attenuates $M D A-M B-231$ cell migration in response to wound scratch}

To examine the effect of dillapiole on MDA-MB-231 cell migration, we employed an in vitro assay. Here, we show that $50 \mu \mathrm{M}$ of dillapiole induces apoptosis on MDA-MB-213 cells. However, we used $25 \mu \mathrm{M}$ dillapiole to investigate whether the anti-proliferative effects correlate with the inhibition of cell migration. Cell migration was significantly $\left({ }^{* * *} p<0.001\right.$ ) inhibited by $25 \mu \mathrm{M}$ dillapiole when compared to untreated cells and an increased rate of wound healing could be observed at all time points examined (Fig. 7A and B).

\subsection{Dillapiole induces apoptosis in MDA-MB-231 cells}

Apoptosis is a strategy of tumor elimination involving a number of signal pathways. To investigate the molecular mechanism of dillapiole-mediated cell apoptosis, we evaluated whether the externalization of phosphatidylserine (PS), a hallmark of early apoptosis, might be involved. In comparison with untreated cells, the treatment with dillapiole at $25 \mu \mathrm{M}$ induces apoptosis in MDAMB-231 cells. Of note, the exposure of PS residues on the outer surface of the plasma membrane was more significant $\left({ }^{* * *} p<0.001\right)$ upon treatment with $50 \mu \mathrm{M}$ dillapiole. Interestingly, we also demonstrate that dillapiole, at the higher concentration, significantly induces necrosis instead of apoptosis (Fig. 8A and B). These results corroborate the data showing that dillapiole-induced apoptosis is mediated by a mitochondria-dependent pathway. It is interesting to note that inhibition of cancer cell growth occurs most likely by apoptosis instead of via cytostatics mechanisms.
A
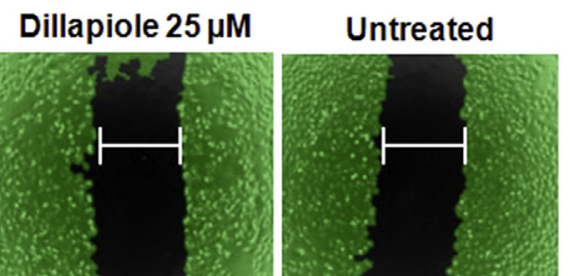

$6 \mathrm{~h}$
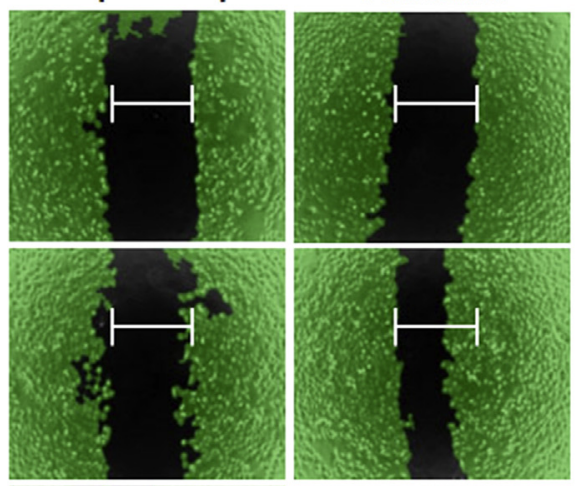

$12 \mathrm{~h}$
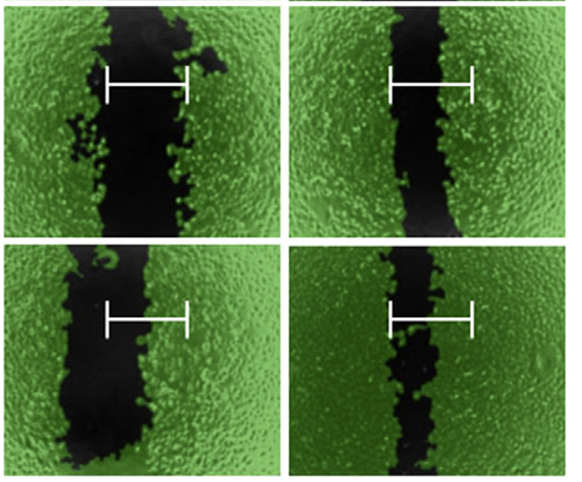

24h
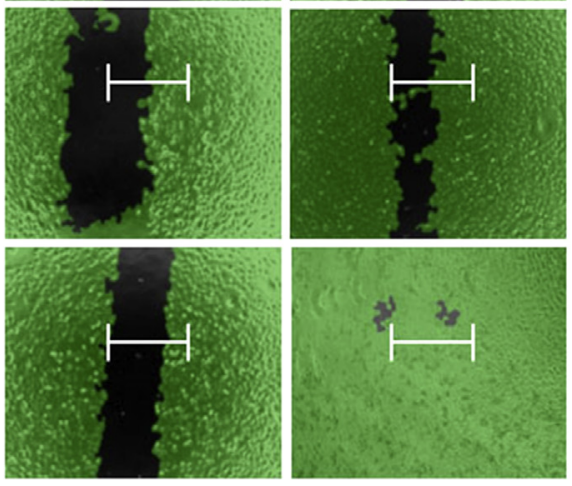

$\mathbf{B}$

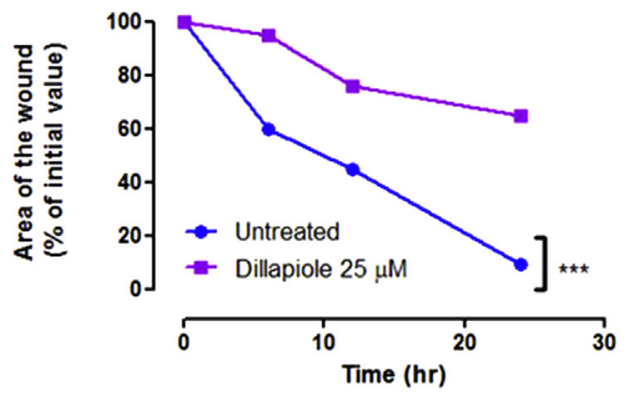

Fig. 7. Effect of dillapiole on MDA-MB-231 cell migration. (A) MDA-MB-231 cells were seeded in a 12-well plate, then scraped to create a clean $1 \mathrm{~mm}$ wide wound area. Cells then were treated for $24 \mathrm{~h}$ with dillapiole at concentrations $25 \mu \mathrm{M}$ and photographed and measured at 0 (t0), 6, 12, and $24 \mathrm{~h}$ after wounding. The wound areas were then analyzed and calculated using online image analysis software Wimasis. (B) Significant differences are indicated as: ${ }^{* * *} p<0.001$ statistically different from the dillapiole versus untreated.

\subsection{Dillapiole induces mitochondrial membrane potential ( $\Delta \psi \mathrm{m})$ disruption in MDA-MB-231 cells}

To evaluate whether apoptosis induced by dillapiole in MDA-MB213 cells is associated with the changes in $\Delta \psi \mathrm{m}$, cells were stained with mitotracker, a cationic fluorophore that accumulates in mitochondria and treated with $25 \mu \mathrm{M}$ or $50 \mu \mathrm{M}$ dillapiole for $6 \mathrm{~h}$. The percentage of stained cells and the total fluorescence intensity were determined by flow cytometry. In untreated cells, red mitochondria could be seen by confocal laser scanning microscopy throughout the cytoplasm without morphological changes indicating a high $\Delta \psi \mathrm{m}$. In contrast, cells treated with both concentrations of dillapiole showed a reduction in the intensity of fluorescent staining and the formation of peripheral clusters could be observed (Fig. 9A). Our investigation by flow cytometry confirms that dillapiole $24 \mathrm{~h}$ reduces significantly $\left({ }^{* * *} p<0.001\right) \Delta \psi \mathrm{m}$ in MDA-MB-213 cells, which can lead to an increase mitochondrial permeability transition (MPT). It demonstrates that dillapiole can induce apoptosis trough the mitochondrial pathway (Fig. 9B and C). 


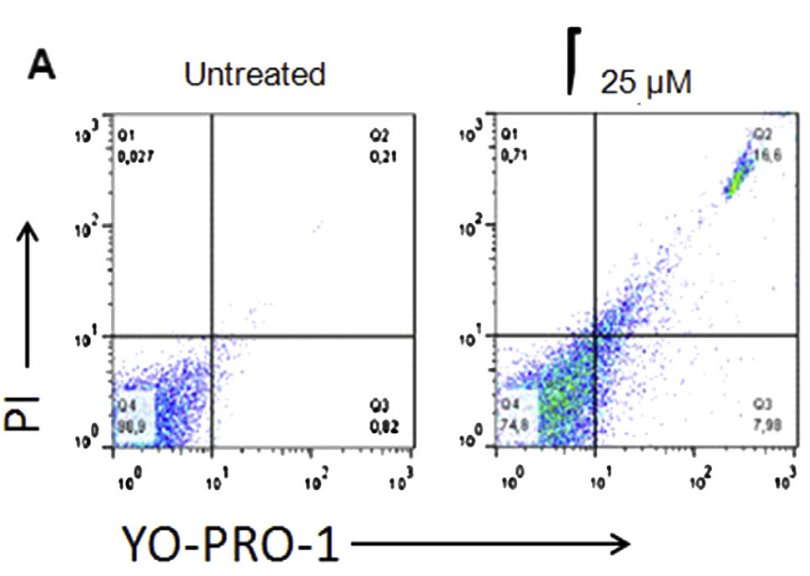

\section{Dillapiole}
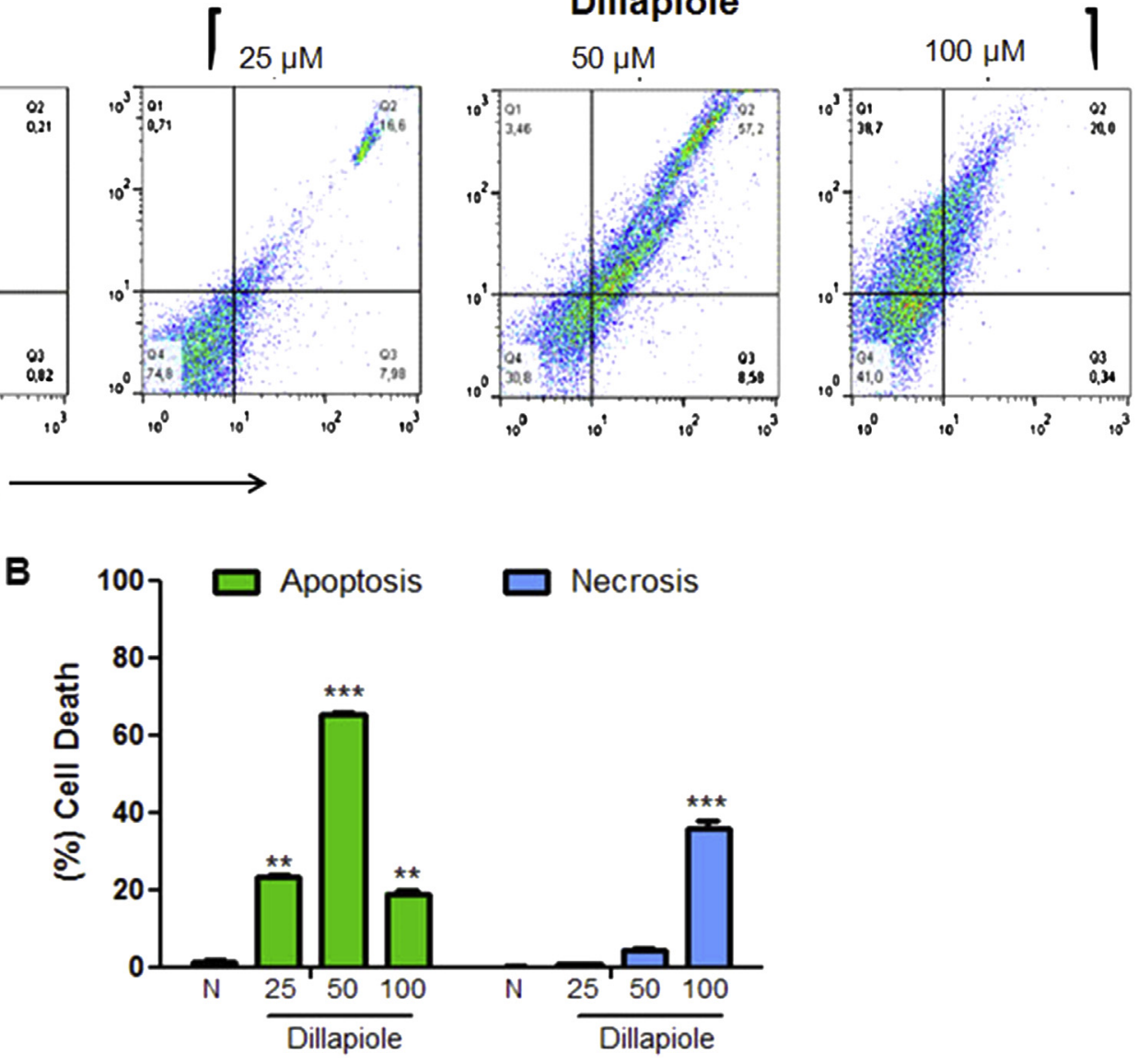

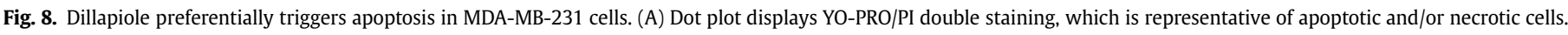

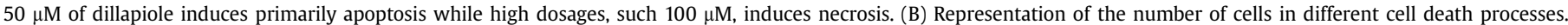
Significant differences between dillapiole and untreated are indicated as: ${ }^{* * *} p<0.001$ and ${ }^{* *} p<0.001$.

\subsection{Treatment with dillapiole induces transient $\left[\mathrm{Ca}^{2+}\right] \mathrm{i}$ in $\mathrm{MDA}-$ MB-231 cells}

Calcium is an important second messenger involved in several intracellular responses that can determined the fate of cells, such as NO production or ER stress, and a number of pro-apoptotic drugs induce mobilization of this ion. Our results show that $25 \mu \mathrm{M}$ dillapiole induce a transient influx of extracellular calcium from intracellular compartments. Notably, we observed that treatment with dillapiole promotes calcium release increasing fluorescence by around 30 units in MDA-MB-231 cells (Fig. 10).

\subsection{Dillapiole triggers a rapid disruption of the cytoskeleton and increases ROS production during apoptosis of MDA-MB-231 cells}

To further evaluate the details of the apoptotic effects of dillapiole on MDA-MB-231 cells, the cytoskeleton and nuclei were stained with phalloidin and PI, respectively. In untreated cells, an examination of the cytoskeleton and nuclei after $12 \mathrm{~h}$ of dillapiole treatment showed a large number of long actin filaments. In addition, several tumor cells containing multiple nuclei could be seen. In MDA-MB-231 cells treated with $25 \mu \mathrm{M}$ dillapiole, an important retraction of actin filaments with formation of short filaments and an increase of ROS production were observed in the cytoplasm. This can cause a disruption of focal adhesions, which, in turn, inhibits binding of cells to the matrix, triggering apoptosis. In contrast, treatment with $50 \mu \mathrm{M}$ dillapiole led to nuclear fragmentation and complete disruption of actin filaments. Notably, stained microfilaments were observed clustered at the sites of apoptotic bodies formation (Figs. 11 and 12).

\subsection{Dillapiole induces caspase-3 activity and cytochrome $c$ release in $M D A-M B-231$ cells}

Ac-YVAD-AMC, a specific caspase-3 substrate, was used to determine whether the mitochondrial pathway cascade is involved in the induction of apoptosis by dillapiole on MDA-MB-231 cells. Cells were treated for $12 \mathrm{~h}$ with dillapiole at the concentration of $25 \mu \mathrm{M}$ or $50 \mu \mathrm{M}$. After treatment, caspase-3 activity was measured through a fluorometric assay. Here, we demonstrated that dillapiole caused a marked induction of apoptosis in MDA-MB-231 cells by increasing caspase-3 activity. Next, we investigated whether the release of cytochrome $c$ was accompanied by an increase of caspase- 3 activity. Interestingly, this correlation was observed with the treatment with dillapiole at both concentrations tested (Fig. 13A). Additionally, dillapiole is able to induce apoptosis through the intrinsic mitochondrial pathway in MDA-MB-231 cells. However, $50 \mu \mathrm{M}$ dillapiole was significantly $\left({ }^{* * *} p<0.001\right)$ more effective in the induction of cytochrome $c$ release than $25 \mu \mathrm{M}$ $\left({ }^{* *} p<0.01\right)$ (Fig. 13A).

\section{Discussion}

Therapeutic regimens, aiming at cancer eradication, encompass both radiotherapy and chemotherapy and, in advanced cases, when traditional treatment fails, tumor resection figures as the last 
A
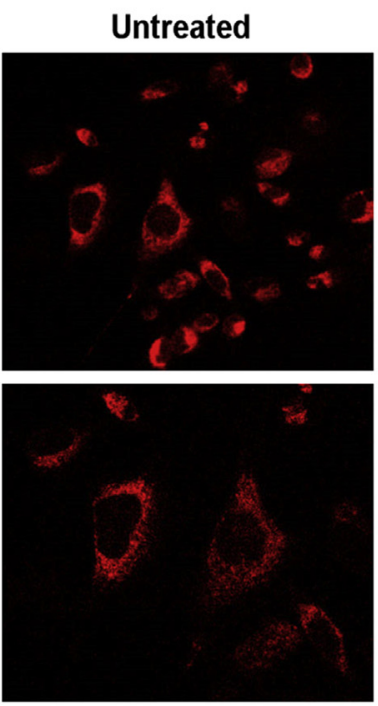

Dillapiole
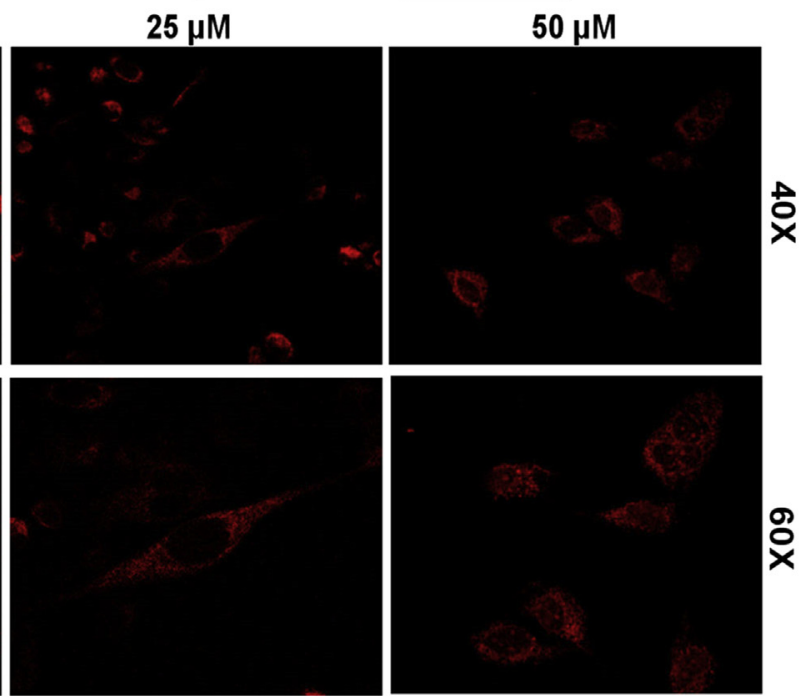

$\hat{\dot{x}}$

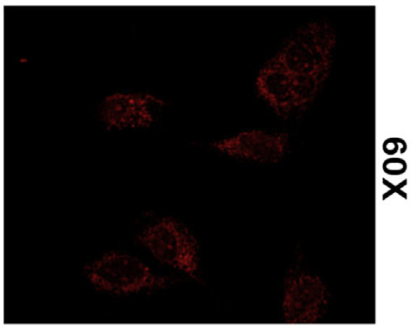

B

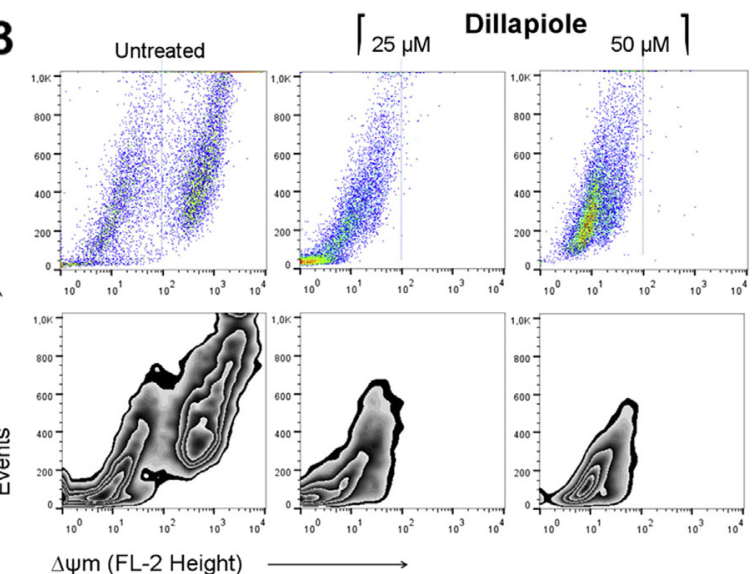

C

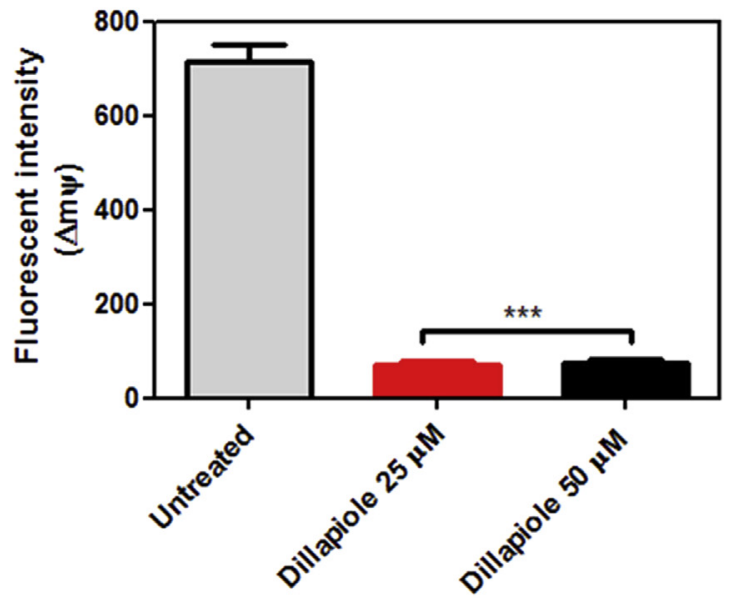

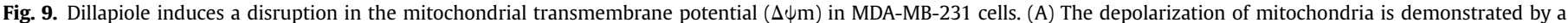

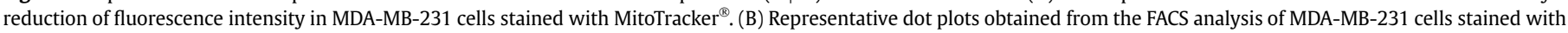

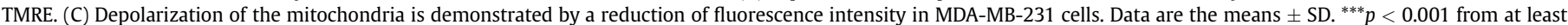
three independent experiments.

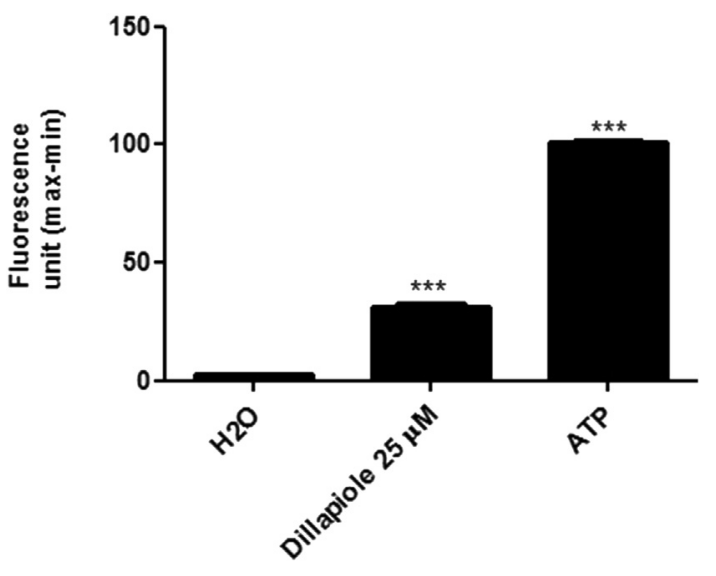

Fig. 10. Characterization of dillapiole-induced $\left[\mathrm{Ca}^{2+}\right]$ i elevations in MDA cells. Changes of maximal peak heights of $\left[\mathrm{Ca}^{2+}\right]$ i responses induced by dillapiole $25 \mu \mathrm{M}$ were measured in MDA cells by microfluorometry. ATP was used as a positive control and $\mathrm{H}_{2} \mathrm{O}$ as a negative control. option [36]. In those advanced cases, eventually, tumor resection might not bring good prognosis, contributing to a decline in life quality, or even lead to death. Therefore, the search for and the development of new therapeutics targeting cancer cells must continue [37]. Here, we used several methods to describe the antitumor effects of dillapiole on MDA-MB-231 cells. Moreover, molecular modeling findings helped us to elucidate some relevant properties that make dillapiole as an excellent hit for anticancer drug discovery.

Regarding to the calculated molecular properties, they support the hydrophilic/hydrophobic balance of dillapiole $(\mathrm{ClogP}=2.38)$, particularly the MLP property (color scheme, Fig. 3B). The positive ClogP value also indicates a more hydrophobic character for this molecule. Regarding the MEP property, dillapiole molecular surface is more neutral/positively (green to blue) than negatively (yellow to red) charged (Fig. 3C). In conclusion, this property could facilitate the interaction with the tumor cell, which has generally a more negatively charged membrane.

Regarding our antitumoral assays, one of our most important results shows that dillapiole is cytotoxic to all tumor cell lines 


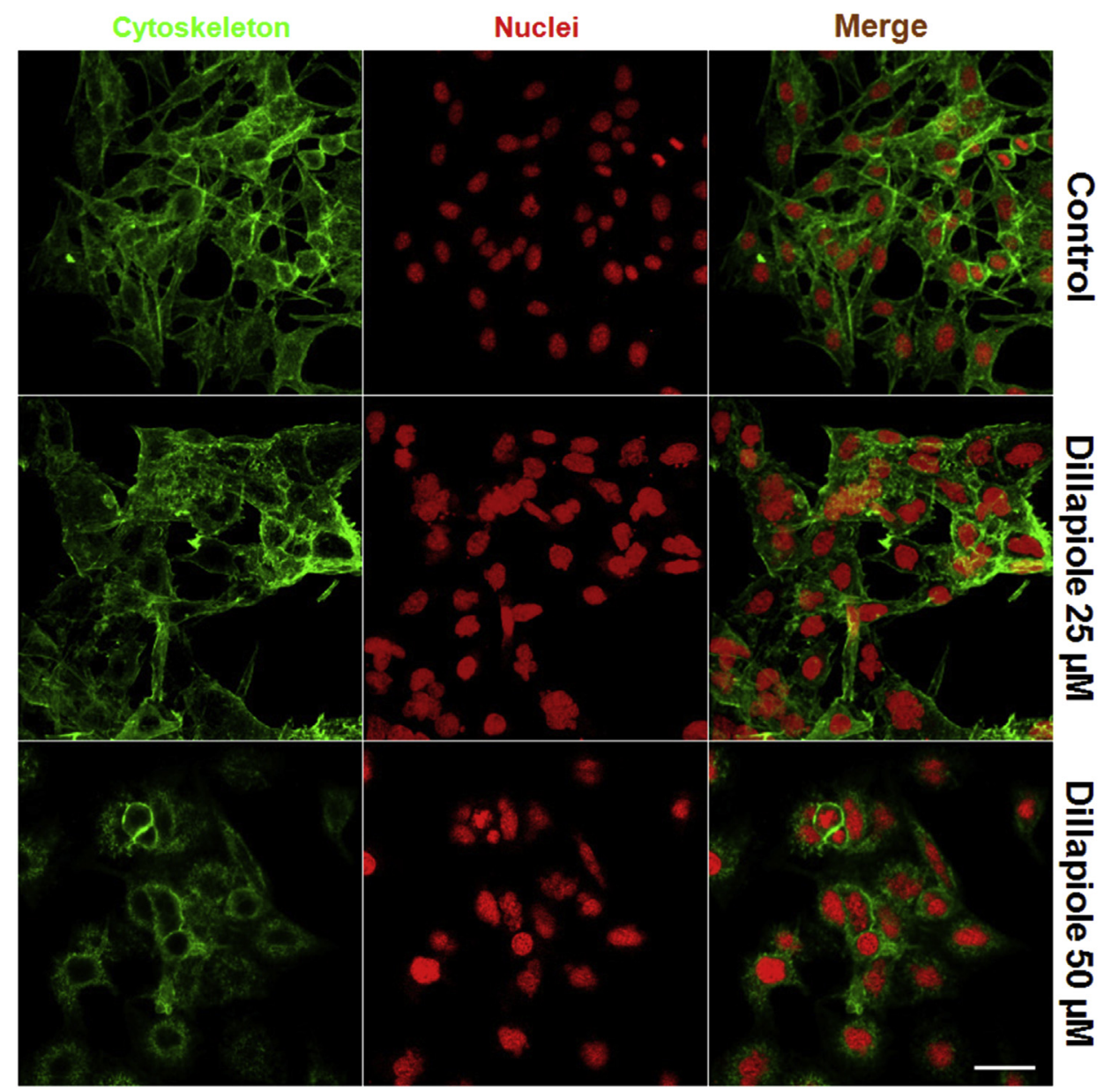

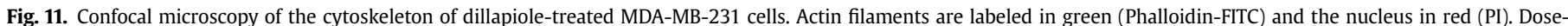
dependent failure in actin polymerization/depolymerization dynamics induced by dillapiole, compared to control, leading to cell morphology changes (Magnification $60 \times$ ).

screened. Interestingly, the different levels of dillapiole cytotoxicity did not correlate with the obtained $\mathrm{IC}_{50}$ values. This finding, though preliminary, suggests that dillapiole can be cytotoxic to the tumor cells tested independently of their sensitivity level. Furthermore, cytotoxic potency of dillapiole on MDA-MB-231 cells was reduced when cells were pre-treated with the pan-caspase inhibitor, z-VAD$\mathrm{fmk}$, and the inhibitor of ROS production, Trolox ${ }^{\circledR}$. It was the first evidence that dillapiole could be acting as a pro-oxidant agent, mediating an increase of intracellular concentration of ROS, which in turn would induce cell damage and cell death in a caspasedependent manner. In order to complement our results showing that dillapiole induces ROS release in MDA-MB-231 cells, we also demonstrate that ROS accumulates in the cytoplasm, subsequently inducing cell death [38]. Of note, increase of ROS in cytoplasm and in mitochondrial compartment is considered a key step in the induction of cell death. It can also induce caspase activation, which in turn leads to apoptosis. These data suggest that the decrease in the cytotoxic effects of dillapiole could be associated with caspases inhibition. Indeed, the presence of ROS and caspases may play a crucial role in the antitumor activity of dillapiole on MDA-MB-231 cells. However, ROS can also induce cell death by necrosis through ATP depletion $[39,40]$. This led us to investigate whether dillapiole induces apoptosis in MDA-MB-231 cells. The first evidence that dillapiole has apoptotic effects on MDA-MB-231 cells is an increase

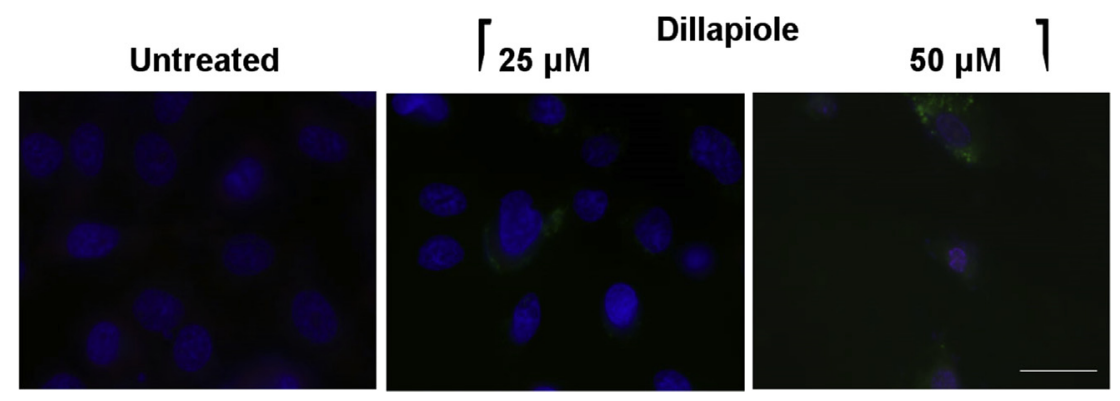

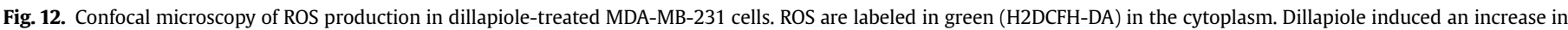
ROS release after $24 \mathrm{~h}$ of treatment, as compared to the untreated cells. (Magnification $60 \times$ ). 
A
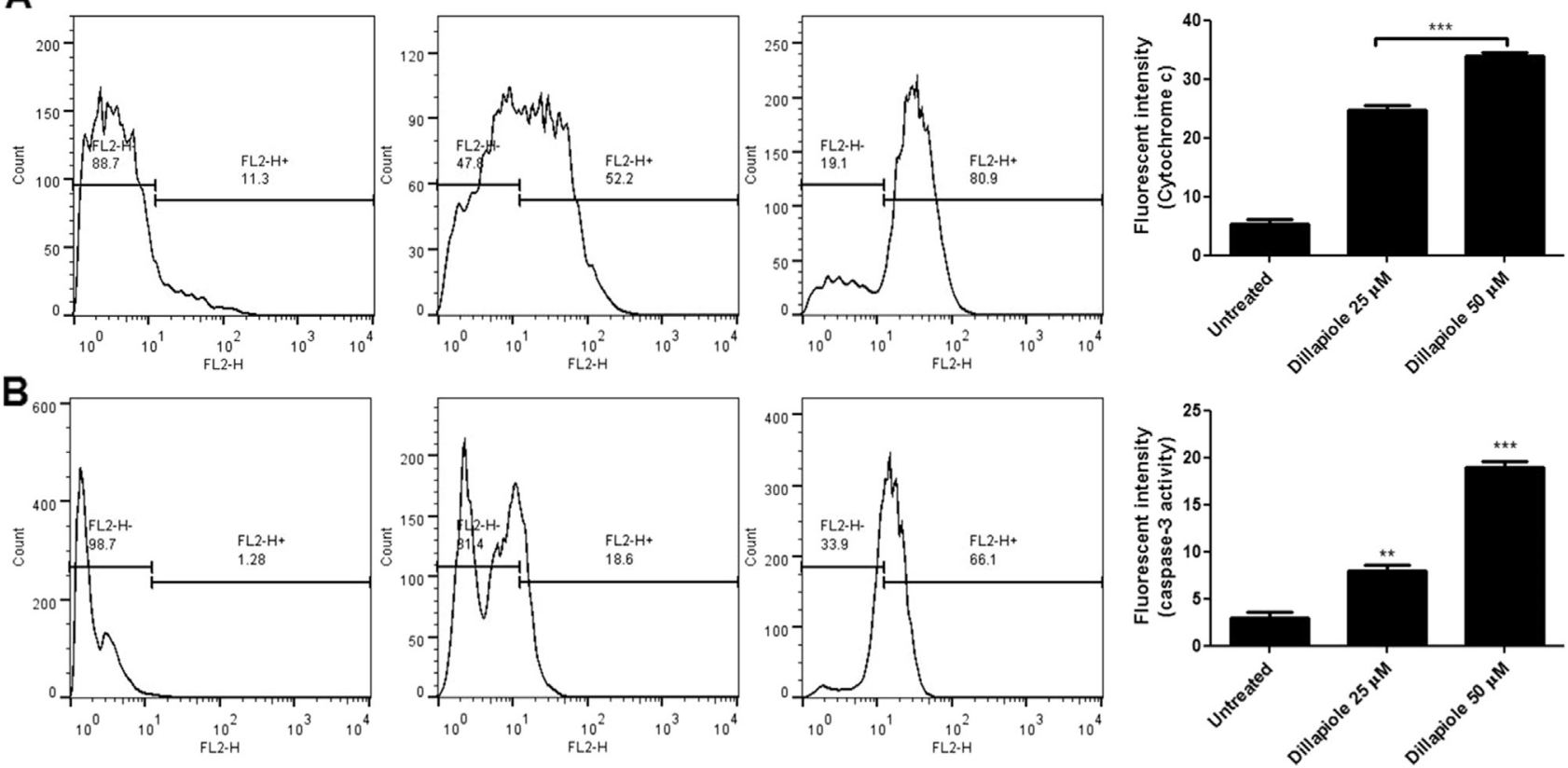

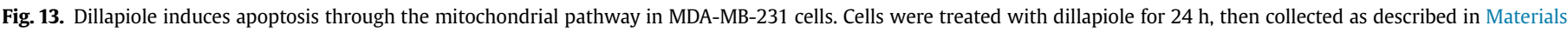

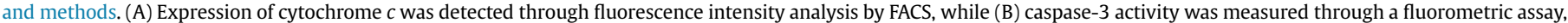
using a specific substrate, Ac-YVAD-AMC. Data are the means \pm SD. ${ }^{* *} p<0.001$ and ${ }^{* *} p<0.001$ from at least three independent experiments.

of the sub-G1 peak. Apoptotic cells can display drastic alterations, with loss of cytoplasmic membrane integrity, and then appear in sub-G1 [41]. We also show that dillapiole exerts an anti-proliferative activity on MDA-MB-231 cells by arresting them in the G0/G1 phase, though a thorough investigation of the mechanism involved is still needed.

Next, we sought to determine whether dillapiole blocks MDAMB-231 cells migration. Interestingly, suppression of MDA-MB231 cancer cells migration by dillapiole was probably caused by arrest at the G0/G1 phase of the cell cycle. Therefore, our major finding was that dillapiole inhibits the migration of tumor cells, which is an important step required for breast cancer metastasis [42]. Since dillapiole inhibits cell migration, the next step was to investigate whether the disruption of the cytoskeleton might be mechanistically involved in the antimigration activity. We found that dillapiole does affect the cytoskeleton organization, inducing a remarkable cytoplasm retraction, which, in turn, affects cell architecture, growth, motility and survival. Indeed, the two latter events are crucial steps for tumor spreading as well as are related to poor outcomes in cell survival and motility [43]. Whether this process results from the direct effect of dillapiole on actin fibers or it is due to ROS generation remains under investigation. Nevertheless, we suggest that dillapiole is able to inhibit tumor proliferation through the disruption of actin filaments in MDA-MB-231 cells.

To further investigate MDA-MB-232 cells death induced by dillapiole, the cells were stained with YO-PRO-1/PI and subjected to flow cytometry. Dillapiole induces apoptosis at all concentrations tested, and that kind of action can in turn be associated with its prooxidant effects. Accordingly, the number of cells dead by apoptosis increased when cells were treated with $50 \mu \mathrm{M}$ dillapiole. Additionally, morphological changes related to apoptosis, such as cell detachment and cell rounding, shrinkage and blebbing formation were observed. In contrast, dillapiole at $100 \mu \mathrm{M}$ concentration induced necrosis, indicating that its apoptotic effects depend on concentration. It is therefore likely that such effects could be mediated by a strong ROS production when dillapiole is used at higher concentrations $(100 \mu \mathrm{M})$. Also, an imbalance between the production and neutralization of ROS may cause catastrophic effects to cells, such as the inactivation of proteins, the degradation of lipids and DNA, culminating in necrosis [44]. Moreover, it is noteworthy that dillapiole, at a lower concentration $(25 \mu \mathrm{M})$, induces apoptosis of MDA-MB-231 cells, which are known to be resistant to apoptosis [45].

The induction of cell death by apoptosis is a well-known strategy for the development of chemotherapeutic agents in the fight against cancer [46]. As discussed above, our findings show that dillapiole has antitumor effects on MDA-MB-231 cells through the induction of apoptosis. Our investigations regarding ROS release induced by dillapiole, indicate that it is a sufficient condition to trigger apoptosis through the mitochondrial pathway in MDA-MB231 cells. Accordingly, the collapse of $\Delta \psi \mathrm{m}$ and the simultaneous increase in $\left[\mathrm{Ca}^{2+}\right]$ i can result in the activation of a wide variety of $\mathrm{Ca}^{2+}$-sensitive enzymes $[47,48]$. It may generate signaling molecules for the recruitment of the mitochondrial apoptotic pathway in MDA-MB-231 cells and, consequently, trigger the activation of effector caspases. In this study, using Ac-YVAD-AMC, a specific caspase- 3 substrate, we confirmed that dillapiole induces apoptosis through the mitochondrial-dependent pathway in MDA-MB-231 cells. Indeed, the release of cytochrome $c$ to the cytosol from the mitochondria during apoptosis induced by dillapiole can, in turn, provoke rearrangement and heptaoligomerization of Apaf-1, namely, the apoptosome $[49,50]$. The apoptosome is responsible for activation of the initiator caspases, such as caspase-9, which sequentially can directly activate caspase-3, an enzyme responsible for the inter-nucleosomal DNA fragmentation, an important feature of apoptotic cell death that can be associated with our in vitro outcome. Based on these data, it is reasonable to suggest that the increase in caspase- 3 activation induced by dillapiole is mediated by the release of cytochrome $c$.

In conclusion, we have demonstrated here, for the first time, that dillapiole has broad cytotoxic effects against a variety of tumor cells. For instance, we found that dillapiole can act as a pro-oxidant compound through the induction of ROS release in MDA-MB-231 cells. We also demonstrate that dillapiole exhibits anti- 


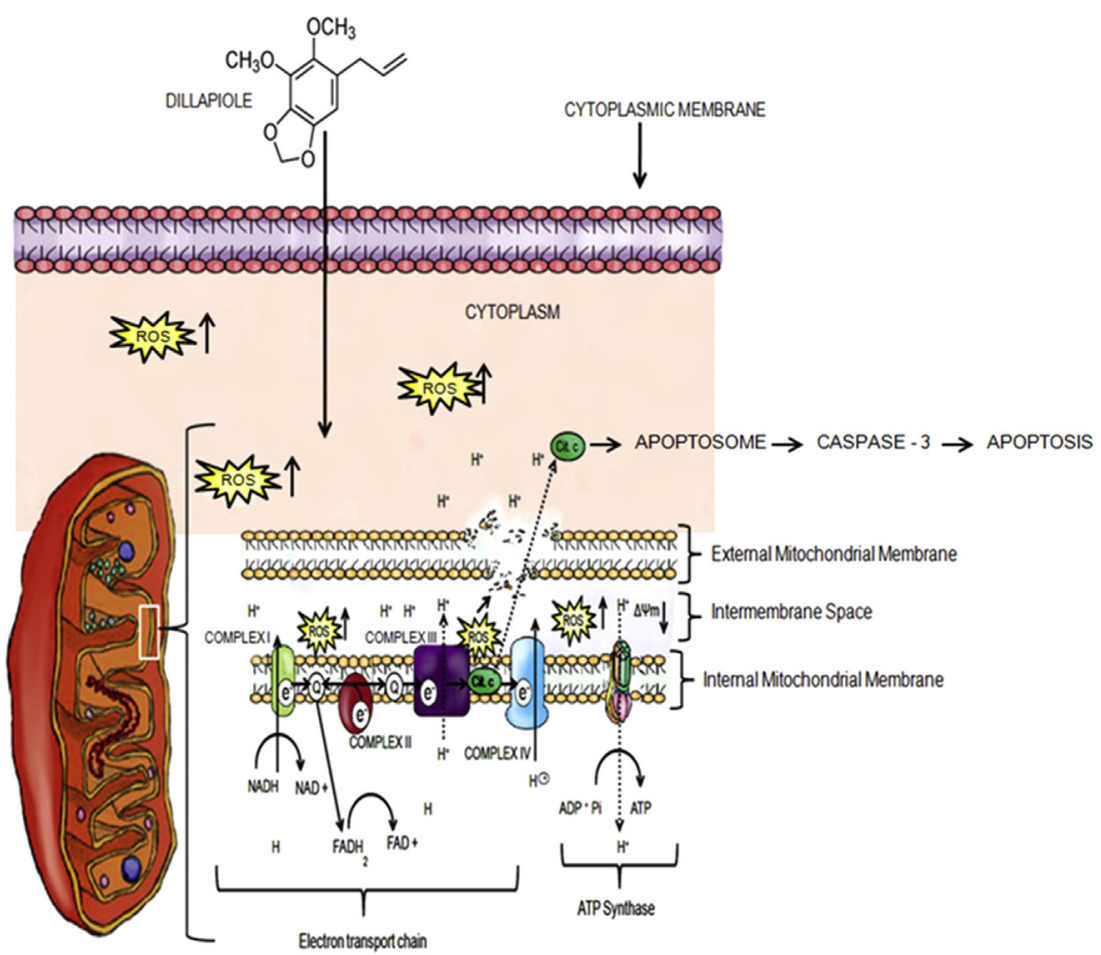

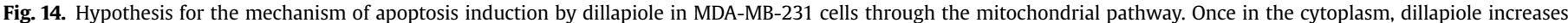

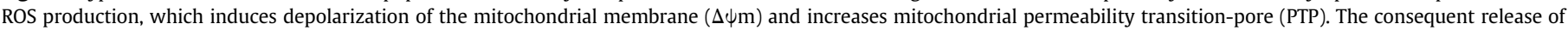
cytochrome $c$ into the cytoplasm induces apoptosis through the activation of caspase- 3 .

proliferative properties, arresting cells at the G0/G1 phase. Additionally, its antimigration effects can be associated with the disruption of actin filaments, which in turn can prevent tumor cell metastasis. A model of the mechanisms of dillapiole-induced cell death by apoptosis is presented in Fig. 14. Dillapiole stimulates ROS production, that subsequently induces mitochondrial dysfunction, cytochrome $c$ release, triggering caspase-3 activation, which results in cell apoptosis. Further investigations are needed to more precisely understand the mechanism of dillapiole-induced ROS release in MDA-MB-231 cells. The next step is to perform an evaluation of dillapiole antitumor effects in a preclinical model to establish a therapeutic hypothesis. Overall, dillapiole is a compound that has potential in vitro anticancer effects, suggesting that it is a promising hit in the fight against cancer.

\section{Competing interests}

The authors have declared that no competing interests exist.

\section{Acknowledgments}

The authors are grateful to the Provost's Office for Research of University of Sao Paulo for financial support, to Professor Leoberto Costa Tavares, coordinator of Laboratory for Designing and Development of New Drugs, Department of Biochemical and Pharmaceutical Technology, Faculty of Pharmacy at University of Sao Paulo, whom kindly allowed the use of a workstation to perform the in silico analysis, and to the Chem21 Group, Inc., for the MOLSIM 3.2 software academic license.

\section{References}

[1] A. Jemal, R. Siegel, E. Ward, T. Murray, J. Xu, M.J. Thun, Cancer statistics, CA Cancer J. Clin. 57 (2007) 43-66.
[2] J.T. Ribeiro, L.T. Macedo, G. Curigliano, L. Fumagalli, M. Locatelli, M. Dalton, A. Quintela, J.B. Carvalheira, S. Manunta, L. Mazzarella, J. Brollo, A. Goldhirsch, Cytotoxic drugs for patients with breast cancer in the era of targeted treatment: back to the future? Ann. Oncol. 23 (2012) 547-555.

[3] J.J. Jobsen, J. Van-der-Palen, M. Brinkhuis, F. Ong, H. Struikmans, Sequence of radiotherapy and chemotherapy in breast cancer after breast-conserving surgery, Int. J. Radiat. Oncol. Biol. Phys. 82 (2012) e811-817, http:// dx.doi.org/10.1016/j.ijrobp.2011.11.020.

[4] P.G. Tsoutsou, Y. Belkacemi, J. Gligorov, A. Kuten, H. Boussen, N. Bese M.I. Koukourakis, Optimal sequence of implied modalities in the adjuvant setting of breast cancer treatment: an update on issues to consider, Oncologist 15 (2010) 1169-1178.

[5] G. Llaverias, C. Danilo, I. Mercier, K. Daumer, F. Capozza, T.M. Williams, F. Sotgia, M.P. Lisanti, P.G. Frank, Role of cholesterol in the development and progression of breast cancer, Am. J. Pathol. 178 (2011) 402-412, http:// dx.doi.org/10.1016/j.ajpath.2010.11.005.

[6] J. Gao, W.A. Morgan, A. Sanchez-Medina, O. Corcoran, The ethanol extract of Scutellaria baicalensis and the active compounds induce cell cycle arrest and apoptosis including upregulation of p53 and Bax in human lung cancer cells Toxicol. Appl. Pharmacol. 254 (2011) 221-228.

[7] J.W. Li, J.C. Vederas, Drug discovery and natural products: end of an era or an endless frontier? Science 325 (2009) 161-165.

[8] T.G. Yunker, The Piperaceae of Brazil: I-Piper-group I, II, III, IV, Hohenia 2 (1972) 19-366.

[9] V.S. Parmar, S.C. Jain, K.S. Bisht, R. Jain, P. Taneja, A. Jha, O.D. Tyagi, A.K. Prasad J. Wengel, C.E. Olsen, P.M. Boll, Phytochemistry of the genus Piper, Phytochemistry 46 (1997) 597-673.

[10] R.R.P. Almeida, R.N.P. Souto, C.N. Bastos, M.H.L. da Silva, J.G.S. Maia, Chemical variation in Piper aduncum and biological properties of its dillapiole-rich essential oil, Chem. Biodivers. 6 (2009) 1427-1434.

[11] C.B. Bernard, H.G. Krishnamurty, D. Chauret, T. Durst, B.J.R. Philogène, P. Sánchez-Vindas, C. Hasbun, L. Poveda, L. San Román, J.T. Arnason, Insecticidal defenses of Piperaceae from the neotropics, J. Chem. Ecol. 21 (1995) $801-813$.

[12] J.W. Lorder, R.H. Neam, Constituents from Piper banksii, Phytochemistry 11 (1972) 2645-2646.

[13] A.P. Martins, L. Salgueiro, R. Vila, F. Tomi, S.C. Igueral, J. Casanova, A.P. Cunha, T. Adzet, Essential oils from four Piper species, Phytochemistry 49 (1998) 2019-2023.

[14] O. Ekundayo, I. Laakso, R.M. Adegbola, B. Oguntimein, A. Sofowora R. Hiltunen, Essential oil constituents of Ashanti pepper (Piper guineense) fruits (berries), J. Agric. Food Chem. 36 (1988) 880-882.

[15] J.W. Loder, A. Moorhouse, G.B. Russell, Tumour inhibitory plants. Amides of Piper novae-hollandiae (Piperaceae), Aust. J. Chem. 22 (1969) 1531-1538. 
[16] L.S. Ramos, M.L. Silva, A.I.R. Luz, M.G.B. Zoghbi, J.G.S. Maia, Essential oil of Piper marginatum, J. Nat. Prod. 49 (1986) 712-741.

[17] R. Parise-Filho, K.F.M. Pasqualoto, F.M.M. Magri, A.K. Ferreira, B.A.V.G. DaSilva, M.C.F.C.B. Damião, M.T. Tavares, R.A. Azevedo, A.V.V. Auada, M.C. Polli, C.A. Brandt, Dillapiole as antileishmanial agent: discovery, cytotoxic activity and preliminary sar studies of dillapiole analogues, Arch. Pharm. 345 (2012) 934-944.

[18] R. Parise-Filho, M. Pastrello, C.E.P. Camerlingo, G.J. Silva, L.A. Agostinho, T. Souza, F.M.M. Magri, R.R. Ribeiro, C.A. Brandt, M.C. Polli, The antiinflammatory activity of dillapiole and some semisynthetic analogues, Pharm. Biol. 49 (2011) 1173-1179.

[19] M.J.C. Araújo, C.A.G. Câmara, F.S. Born, M.M. Moraes, C.A. Badji, Acaricida activity and repellency of essential oil from Piper aduncum and its components against Tetranychus urticae, Exp. Appl. Acarol. 57 (2012) 139-155.

[20] E.H.A. Andrade, L.M.M. Carreira, M.H.L. Silva, J.D. Silva, C.N. Bastos, P.J.C. Sousa E.F. Guimarães, J.G.S. Maia, Variability in essential-oil composition of Piper marginatum sensu lato, Chem. Biodivers. 5 (2008) 197-208.

[21] P.P. Diaz, B.C. Ramos, G.E. Matta, New $C_{6}-C_{3}$ and $C_{6}-C_{1}$ compounds from Piper lenticellosum, J. Nat. Prod. 49 (1986) 690-691.

[22] C.B. Bernard, H.G. Krishinamurty, D. Chauret, T. Durst, B.J.R. Philogene, P. Sanchés-Vindas, C. Hasbaun, L. Poveda, L.S. Roman, J.T. Arnason, Inseticidal defenses of Piperaceae from the neotropics, J. Chem. Ecol. 21 (1995) 801-814.

[23] M. Fazolin, J.LV. Estrela, V. Catani, M.S. Lima, M.R. Alécio, Toxicidade do óleo de Piper aduncum L. a adultos de Cerotoma tingomarianus Bechyné (Coleóptera: Chrysomelidae), Neotrop. Entomol. 34 (2005) 485-489.

[24] V.A. Facundo, A.S.P. Silveira, S.M. Morais, Constituents of Piper alatabacum Tre \& Yuncker (Piperaceae), Biochem. Syst. Ecol. 33 (2005) 753-756.

[25] F.S. Yu, J.S. Yang, C.S. Yu, C.C. Lu, J.H. Chiang, C.W. Lin, J.G. Chung, Safrole induces apoptosis in human oral cancer HSC-3 cells, J. Dent. Res. 90 (2011) $168-174$

[26] C.S. Yu, A.C. Huang, J.S. Yang, C.C. Yu, C.C. Lin, H.K. Chung, Y.P. Huang, F.S. Chueh, J.G. Chung, Safrole induces G0/G1 phase arrest via inhibition of cyclin $\mathrm{E}$ and provokes apoptosis through endoplasmic reticulum stress and mitochondrion-dependent pathways in human leukemia HL-60, cells, Anticancer Res. 32 (2012) 1671-1679.

[27] P. Ala, D.S.C. Yang, 6-[1-(4-Ethoxyphenyl)ethyl]-5-methoxy-1,3benzodioxole, Acta Crystallogr. C51 (1995) 1917-1919.

[28] M.J.S. Dewar, E.G. Zoebisch, E.F. Healy, J.J.P. Stewart, AM1: a new general purpose quantum mechanical molecular model, J. Am. Chem. Soc. 107 (1985) 3903-3909.

[29] D. Doherty, MOLSIM: Molecular Mechanics and Dynamics Simulation Software - User's Guide, Version 3.2, The Chem21 Group Inc., Lake Forest, IL, 2002.

[30] C.M. Breneman, K.B. Wiberg, Determining atom-centered monopoles from molecular electrostatic potentials. The need for high sampling density in formamide conformational analysis, J. Comput. Chem. 11 (1990) 361-373.

[31] A.D. Becke, A new mixing of Hartree-Fock and local density-functional theories, J. Chem. Phys, 98 (1993) 1372-1377.

[32] M.A. Robb, J.R. Cheeseman, J.A. Montgomery, T. Vreven, K.N. Kudin, J.C. Burant, J.M. Millam, S.S. Iyengar, J. Tomas, E.V. Baron, B. Mennucci, M. Cossi, G. Scalmani, N. Rega, G.A. Petersson, H. Nakatsuji, M. Hada, M. Ehara, K. Toyota, R Fukuda, J. Hasegawa, M. Ishida, T. Nakajima, Y. Honda, O. Kitao, H. Nakai, M Klene, X. Li, J.E. Knox, H.P. Hratchian, J.B. Cross, V. Bakken, C. Adamo, J. Jaramillo, R. Gomperts, R.E. Stratmann, O. Yazyev, A.J. Austin, R. Cammi, C. Pomelli, J.W. Ochterski, P.Y. Ayala, K. Morokuma, G.A. Voth, P. Salvador, JJ. Dannenberg, V.G. Zakrzewski, S. Dapprich, A.D. Daniels, M.C. Strain, O. Farkas, D.K. Malick, A.D. Rabuck, K. Raghavachari., J.B. Foresman, J.V. Ortiz, Q. Cui, A.G. Baboul, S. Clifford, J. Cioslowski, B.B. Stefanov, G. Liu, A. Liashenko, P. Piskorz, I. Komaromi, R.L. Martin, D.J. Fox, T. Keith, M.A. Al-Laham, C.Y. Peng, A Nanayakkara, M. Challacombe, P.M.W. Gill, B. Johnson, W. Chen, M.W. Wong, C. Gonzalez, J.A. Pople, Gaussian, Inc., Wallingford CT, 2004.
[33] GaussView for Windows, version 5.0, Gaussian, Inc., Pittsburgh, PA, 20002008.

[34] V.N. Viswanadhan, A.K. Ghose, G.R. Revankar, R.K. Robins, Atomic physicochemical parameters for three-dimensional-structure-directed quantitative structure-activity relationships. 2. Modeling dispersive and hydrophobic interactions, J. Chem. Inf. Comput. Sci. 29 (1989) 163-172.

[35] Marvin Beans 5.8.0 Software - Calculator Plugins, Chemaxon, Ltd., Budapeste 1037, Hungary, 2012.

[36] R. Emmadi, E.L. Wiley, Evaluation of resection margins in breast conservation therapy: the pathology perspective-past, present, and future, Int. J. Surg. Oncol. 2012 (2012) 1-9.

[37] T. Fukutomi, Clinical practice and outcome of breast-conserving treatment: the effectiveness of preoperative systemic chemotherapy, Breast Cancer 13 (2006) 147-151.

[38] G.V. Park, Y. Choi, Y.S. Kim, H.K. Lee, D. Kim, D.Y. Hur, ROS and ERK1/2mediated caspase-9 activation increases XAF1 expression in dexamethasone-induced apoptosis of EBV-transformed B cells, Int. J. Oncol. 43 (2013) 29-38.

[39] J. Montero, C. Dutta, D. Van-Bodegom, D. Weinstock, A. Letai, p53 regulates a non-apoptotic death induced by ROS, Cell Death Differ. (2013), http:// dx.doi.org/10.1038/cdd.2013.52.

[40] Y.C. Ye, H.J. Wang, L. Yu, S. Tashiro, S. Onodera, T. Ikejima, RIP1-mediated mitochondrial dysfunction and ROS production contributed to tumor necrosis factor alpha-induced L929 cell necroptosis and autophagy, Int. Immunopharmacol. 14 (2012) 674-682.

[41] A. Tinari, A.M. Giammarioli, V. Manganelli, L. Ciarlo, W. Malorni, Analyzing morphological and ultrastructural features in cell death, Meth. Enzymol. 442 (2008) 1-26.

[42] M. Yu, A. Bardia, B.S. Wittner, S.L. Stott, M.E. Smas, D.T. Ting, S.J. Isakoff, J.C. Ciciliano, M.N. Wells, A.M. Shah, K.F. Concannon, M.C. Donaldson, L.V. Sequist, E. Brachtel, D. Sgroi, J. Baselga, S. Ramaswamy, M. Toner, D.A. Haber, S. Maheswaran, Circulating breast tumor cells exhibit dynamic changes in epithelial and mesenchymal composition, Science 339 (2013) $580-584$.

[43] D.X. Nguyen, P.D. Bos, J. Massagué, Metastasis: from dissemination to organspecific colonization, Nat. Rev. Cancer 9 (2009) 274-284.

[44] B. Saberi, M. Shinohara, M.D. Ybanez, N. Hanawa, W.A. Gaarde, N. Kaplowitz, D. Han, Regulation of $\mathrm{H}_{2} \mathrm{O}_{2}$-induced necrosis by PKC and AMP-activated kinase signaling in primary cultured hepatocytes, Am. J. Physiol. Cell Physiol. 295 (2008) c50-63.

[45] A. Ciucci, P. Gianferretti, R. Piva, T. Guyot, T.J. Snape, S.M. Roberts, M.G. Santoro, Induction of apoptosis in estrogen receptor-negative breast cancer cells by natural and synthetic cyclopentenones: role of the IkappaB kinase/nuclear factor-kappaB pathway, Mol. Pharmacol. 70 (2006) 18121821.

[46] A.K. Ferreira, V.W. Freitas, D. Levy, J.L. Ruiz, S.P. Bydlowski, R.E. Rici, O.M. Filho, G.O. Chierice, D.A. Maria, Anti-angiogenic and anti-metastatic activity of synthetic phosphoethanolamine, PLoS One (2013), http://dx.doi.org/10.1371/ journal.pone.0057937.

[47] C. Giorgi, F. Baldassari, A. Bononi, M. Bonora, E. De-Marchi, S. Marchi, S. Missiroli, S. Patergnani, A. Rimessi, J.M. Suski, M.R. Wieckowski, P. Pinton, Mitochondrial $\mathrm{Ca}^{2+}$ and apoptosis, Cell Calcium 52 (2012) 36-43.

[48] L. Scorrano, S.A. Oake, J.T. Opferman, E.H. Cheng, M.D. Sorcinelli, T. Pozzan, S.J. Korsmeyer, BAX and BAK regulation of endoplasmic reticulum $\mathrm{Ca}^{2+}$ : a control point for apoptosis, Science 300 (2003) 135-139.

[49] Q. Hu, D. Wu, W. Chen, Z. Yan, Y. Shi, Proteolytic processing of Caspase-9 zymogen is required for apoptosome-mediated activation of Caspase-9, J. Biol. Chem. 288 (2013) 15142-15147.

[50] S. Yuan, C.W. Akey, Apoptosome structure, assembly, and procaspase activation, Structure 21 (2013) 501-515. 